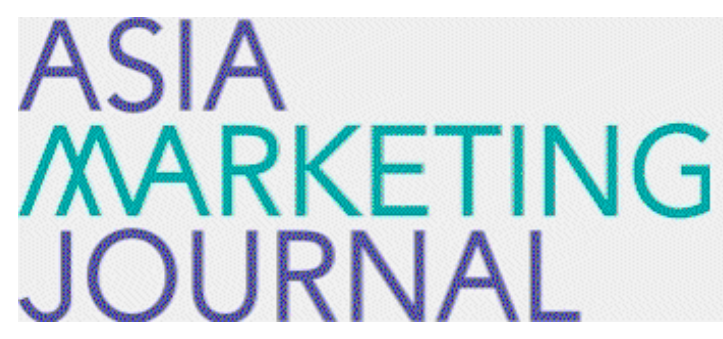

ASIA MARKETING JOURNAL

Volume 8 | Issue 1

Article 6

$4-25-2006$

\title{
산업재 물류에서 환경 불확실성과 물류자원역량이 관계규범과 물 류서비스를 통하여 물류성과에 미치는 영향
}

Dal Young Chun

Hong Sun Kim

Follow this and additional works at: https://amj.kma.re.kr/journal

Part of the Marketing Commons

\section{Recommended Citation}

Chun, Dal Young and Kim, Hong Sun (2006) "산업재 물류에서 환경 불확실성과 물류 자원역량이 관계규범 과 물류서비스를 톨하여 물류성과에 미치는 열향," Asia Marketing Journal: Vol. 8 : Iss. 1 , Article 6. Available at: https://doi.org/10.53728/2765-6500.1164

This Article is brought to you for free and open access by Asia Marketing Journal. It has been accepted for inclusion in Asia Marketing Journal by an authorized editor of Asia Marketing Journal. 


\title{
산업재 물류에서 환경 불확실성과 물류자원역량이 관계규범과 물류서비스를 통하여 물류성과에 미치는 영향*
}

\section{The Impact of Environmental Uncertainty and Logistics Resources Capabilities on Logistics Performance through Relational Norms and Logistics Services in the Industrial Products}

\author{
전 달 영 (Chun, Dal-Young)** \\ 김 홍 선(Kim, Hong-Sun) ${ }^{* * *}$
}

본 논문의 주된 연구목적은 기존연구에서 거의 고려되지 않았던 산업재 구매시장에서의 물류환경특성과 물류자원역량이 관계규범과 물류서비스를 통하여 물류성과에 미치는 영향을 분석하는 것이다. 제안한 연구 가설들을 검정하기 위하여 $\mathrm{H}$ 중공업 및 $\mathrm{HSD}$ 엔진의 구매부, 자재관리부, 수출입관리부, 외주관리부, 수입검 사부 등의 물류관련부서에 종사하는 핵심 응답자로부터 272 부의 설문지를 수집하여 자료분석에 이용하였다.

구조방정식 모형 분석을 통해 알아낸 분석 결과를 연구주제별로 살펴보면 다음과 같다. 첫째. 산업 재구매에서 환경의 역동성, 이질성 등의 물류환경 불확실성은 기대와는 다르게 가용성. 적시성 등의 물류서비스와 정보교환, 유연성 등의 관계규범에 유의한 영항을 미치지 않는 것으로 나타났다. 둘째, 물류자원역량은 구성요인의 특성에 따라 효과가 다르게 나타났다. LIS 등의 물류정보화는 직접적으 로 물류서비스에 영향을 미치지 못하고 관계규범을 통하여 간접적으로 물류서비스에 유의한 영향을 주었고 반면에 물류 거래특유투자. 수송서비스 능력 등의 물류자원은 관계규범에는 영향을 주지 못하 고 직접적으로 물류서비스에 유의한 영향을 미치었다. 셋째, 거래당사자간의 합의된 관계규범은 물류 서비스를 유의하게 높이는 것으로 나타났으나 물류비용절감. 배송의 질 등의 물류성과의 제고에는 별 다른 효과를 나타내지 못하였다. 넷째, 많은 선행연구들의 결과와 일치하게 장기적 관계를 기반으로 하는 산업재구매자와 자재공급업자의 거래에서 관계규범을 바탕으로 한 우수한 물류서비스는 리드타 임 일관성, 배송품질 향상 등의 물류성과에 유의한 영향을 주었다. 마지막으로, 본 논문에서 밝혀진 물류환경, 물류정보화, 물류자원, 관계규범, 물류서비스 및 물류성과 간의 연관관계에 대한 분석결과들 은 산업재 구매자들에게 이론에 근거한 전략적 물류관리 실천방안으로 활용될 수 있을 것이다.

핵심개념: 산업재물류, 환경불확실성, 물류자원역량, 관계규범, 물류서비스, 물류성과

건설적인 의견을 주신 두 분의 심사위원들께 고마움을 표합니다.

이 논문은 2004년도 산학협동재단 학술연구비 지원에 의해 이루어졌음.

** 충북대학교 경영학부 교수(dychun@chungbuk.ac.kr)

*** SUN ALL 대표이사. 경영학박사(suncbnu@hanmail.net) 


\section{I. 서 론}

IT(information technology)산업의 비약적인 발달과 글로벌 시장의 규제완화 환경은 기업에 게 새로운 경쟁전략을 모색케 하며 위기와 기 회를 동시에 제공하고 있다. 정부차원에서는 한 반도를 동북아 물류의 허브로 자리매김하기 위 해 제반시설의 확충과 국내 물류시스템의 개선 을 위해 많은 정책들을 전개하고 있다. 또한 기 업들은 생산기술의 차별화가 더욱 어렵게 됨에 따라 원가 절감을 통한 경쟁력 제고를 모색하 고 있으며 그 일환으로 효율적인 물류시스템의 구축과 물류비용의 절감에 치중하고 있다.

이에 힘입어 우리나라 기업물류비는 2003년 기준 매출액 대비 약 $9.9 \%$ (제조업 약 $10.0 \%$, 유 통업 약 $9.6 \%$ ) 수준으로 나타나 2001년 약 $11.1 \%$ (제조업 약 $11.2 \%$, 유통업 약 $10.3 \%$ )에 비해 상당 부분 감소한 것으로 나타났다. 그러나 물 류선진국 기업들의 평균(미국 약 $5.0 \%$, 일본 약 $7.5 \%$ )과 비교하여 여전히 기업경쟁력을 저 해하는 주요 요인으로 작용하고 있으며, 자재가 격 다음으로 기업경영의 고비용 요인으로 나타 나고 있다(대한상공회의소 2004). 따라서 이제 물류비용은 개별 기업경쟁력 뿐만 아니라 국가 경쟁력과 직결되는 중대한 이슈이다.

전통적인 물류는 판매물류(physical distribution) 로서 상품이 판매자로부터 소비자에게로 이동 되는 과정으로 유통활동의 한 부분으로 인식되 었다. 최근에는 물류개념이 조달물류, 폐기물류 까지 포함하는 로지스틱스(logistics) 개념으로 확대되고 더 나아가 IT의 발달과 더불어 생산 자의 원료조달에서부터 최종소비자에 이르기까
지 재화의 총체적인 흐름을 관리하는 공급사슬 관리(SCM; supply chain management) 개넘 으로 발전하였다. $\mathrm{SCM}$ 환경하에서 정보기 술과 물류시스템의 통합은 웹기반의 전자물류 (e-logistics), 모바일 물류(m-logistics), 그리고 유비쿼터스 네트워크(ubiquitous network)를 접 목한 유비쿼터스 물류(u-logistics)로 진화되어 가고 있다.

그렇다면 이러한 첨단물류 환경하에 제조기업 의 어떠한 물류자원특성과 물류정보시스템 등 이 물류서비스와 물류성과에 영향을 주는지를 조사해 볼 필요가 있다. 외국에서는 물류에 관 한 많은 학문적 연구(cf. Bourlakis and Bourlakis 2005: Kent and Mentzer 2003; Stank 외 2003: Wisner 2003) 들이 수행되고 있지만, 우 리 나라에서는 자료부족 등 여러 가지 이유로 물류의 학술적·실무적 중요성에 비해 연구들이 많지 않은 편이다. 그나마 유통업자나 소매업자 측면에서의 실증조사(예: 전달영, 정창환 1997; 김태현, 문성암 1998) 또는 사례분석(예: 김용 철. 김재일 2001)에 관한 연구들이 이루어졌 으나, 산업재 납품업체와 조직구매자 간의 물 류 교환과정인 산업재 물류 즉, 중물류(heavy logistics)에 대한 연구는 김재욱 외 (2000)을 제외하고는 거의 없는 실정이다. 따라서 산업 재 물류에서의 성공적인 물류관리를 위한 핵심 요인들을 규명하고 이들 구성요인들이 물류성 과에 미치는 영향에 대한 연구가 필요한 시점 이다.

산업재 물류에서는 특히 구매자 관점에서의 물류 즉 구매자가 다수의 납품업자로부터 공급 되는 여러 종류의 원재료나 부품자재를 효율적 으로 관리하는 물류관리의 전반적인 흐름이 중 
요하다(Ballou 2001). 다시 말하면 산업재 물류 의 핵심은 산업재를 공급자로부터 구매자에게 이동시켜 장소효용 및 시간효용 가치를 창출시 키는 물류서비스라 볼 수 있다. 물류서비스는 발주처 고객을 확보할 수 있는 수단적 서비스 활동으로서 물류성과와 직결되는 물류관리의 중요한 요인이다. 따라서 기업은 물류성과를 중 진시키기 위하여 물류비용의 절감 뿐만 아니라 물류서비스의 향상이라는 두 가지 상반된 측면 을 동시에 고려해야 한다.

물류성과를 증진시키는데 있어 산업재 시장에 서의 물류활동은 여러 가지 요인들에 의해 제 약을 받는다. 먼저, 구매위험요소가 존재하는 물류환경의 불확실성이다. 구매환경에 있어 불 확실성은 치열한 납품경쟁 및 구매위험을 유발 시켜 산업재 시장에서 물류거래비용 증가와 물 류서비스 수준에 대한 기대의 차이를 가져올 수 있다.

다음으로 물류서비스와 물류성과를 좌우하는 요인들로 물류정보화(Droge and Germain 2000) 와 물류자원(Olavarrieta and Ellinger 1997)의 물류자원역랑을 들 수 있다. IT산업의 발달은 교환당사자간에 전자적 거래를 통해 실시간으 로 물류정보를 공유하고 구매의사결정을 하기 때문에 산업재 구매에서 물류정보화의 중요성 이 더욱 강조되고 있다. 뿐만 아니라 물류시설 및 시스템을 포함한 물류자원은 산업재 고객이 구매한 자재를 원하는 장소까지 이동시켜 산업 재 고객에게 일관성 있는 장소효용 및 시간효 용(Mentzer, Gomes, and Krapfel 1989) 및 형 태효용을 창출한다. 따라서 물류정보화와 물류 시스템 등의 물류자원역량은 물류서비스를 향 상시키고 궁극적으로 물류성과를 높이기 때문
에 산업재 구매환경에서 중요한 역할을 한다.

또한, 산업재 구매에서 물류서비스 수준을 높 이기 위한 매개수단으로 거래당사자간의 암묵 적인 관계규범(relational norms)이 중요한 역할 을 한다(Macneil 1980; Dahlstrom, McNeilly and Speh 1996; Closs, Swink, and Nair 2005). 장기적인 거래관계를 필요로 하는 산업재의 특 성상 정보교환과 유연성 그리고 결속력을 근간 으로 구성되는 관계규범은 산업재 공급자와 구 매자간의 신뢰를 형성하여 거래관계를 안정되 게 한다.

따라서 본 논문에서는 기존연구에서 거의 고 려되지 않았던 산업재 구매시장에서의 물류한 경특성과 물류자원역량이 관계규범과 물류서비 스를 통하여 물류성과에 미치는 영향을 분석하 는 것을 주된 연구목적으로 한다. 세부적으로, 첫째, 물류 환경의 가변성, 역동성 등의 불확실 성이 정보교환, 유연성 등의 관계규범과 가용 성, 적시성 등의 물류서비스에 주는 영향을 조 사하고, 둘째, 물류정보화와 물류정보시스템이 관계규범과 물류서비스에 주는 영향을 파악하 고, 셋째, 물류 거래특유투자, 수송서비스 능력 등의 물류자원이 관계규범과 물류서비스에 미 치는 영향을 살펴보고, 넷째, 관계규범과 물류 서비스의 상호관련성을 규명하고, 마지막으로, 관계규범과 물류서비스 등이 궁극적으로 물류 성과에 미치는 영향을 분석하고자 한다. 공분산 분석을 통한 연구모형의 실증분석 결과는 물류 환경, 물류정보화, 물류자원, 물류서비스, 관계 규범 및 물류성과 간의 상호연관관계를 밝힘으 로써 산업재 구매자들에게 물류관련 이론적 토 대와 전랴적 물류관리 실천방안을 제시할 수 있을 것이다. 


\section{II. 이론적 배경}

\section{1 물류환경의 불확실성}

기업의 경쟁력과 성과는 환경적 상황에 따라 달라진다. 기업 환경의 불확실성은 일반적으로 환경의 이질성(environmental heterogeneity), 환경의 역동성(environmental dynamism), 환경 의 풍요성(environmental munificence), 그리고 환경의 적대성(environmental hostility) 등으로 나 눌 수 있다(March and Simon 1958: Miller and Friesen 1982: McGinnis and Kohn 1993).

조직이론에서 발전되어온 환경 불확실성의 구 성 요인을 구체적으로 살펴보면 첫째, Thompson (1967)은 환경을 이질성 대 동질성의 두 차원 으로 구분하였다. 이질성은 다양성이 요구되는 마케팅 또는 생산지향적인 기업이 시장에서 직 면하는 변화 정도를 의미하고, 이질성은 조직이 나 개인을 둘러싼 환경요인들간의 유사성 또는 다양성의 정도로 측정된다. 기업들은 시장에서 증가하고 있는 이질성에 대응하기 위하여 제품. 서비스, 기술혁신 등을 통하여 고객맞춤식 차별 화된 시장세분화 전략을 구사한다(Miller and Friesen 1983). 둘째, 환경의 역동성은 환경요인 들이 예측 불가능하게 변화하는지 아니면 예측 가능한지를 의미하며, 환경요인들이 쉽게 변화 하는 정도를 나타내는 가변성 (volitility) 과 환경 요인들의 급격한 변화정도를 나타내는 격변성 (turbulence)의 두 가지 특성으로 나타난다. 역동성은 경쟁자와 고객 행위의 가변성, 예측 불가능성 등에 대한 변화의 정도로 측정된다 (Lawrence and Lorsch 1967: Thompson 1967).
셋째, March and $\operatorname{Simon(1958)ㅇㅡㄴ~ㅎㅗㅇㅢㅈㅓㄱㅇㅣㄴ~}$ 외부환경, 자원의 풍부함 등을 나타내는 개념으 로 환경의 풍요성을 제시하였다. 반면에 Child (1972)는 환경에서 자원의 효용 또는 유용성 측면을 강조하는 희소성(illiberality)이라는 개 념을 제시하였고 이는 풍요성 개념과 대비된다. 넷째, 환경의 적대성은 경쟁의 다중적인 측면 즉 경쟁강도 및 해당산업의 경기하강 등에 의 해 기업에게 전달되는 위협의 수준을 의미한다 (Khandwalla 1977: Miller and Friesen 1982). 환경의 풍요성에 반하여 적대성은 기업에게 자 원 희소성의 증가, 이익의 감소, 그리고 전랴 운용 폭의 축소 등을 경험하게 한다.

마케팅에서는 위에서 언급한 조직이론에서 개 발된 환경 불확실성에 대한 개념들이 유통분야 에서 Achrol, Reve, and Stern(1983), Achrol and Stern(1988)의 정치경제 패러다임 연구를 중심으로 발전되어 왔다. Achrol et al.(1983)은 환경요인들이 유통경로의 내부 정치경제 구조 (예: 경로형태와 관료적 구조화)와 과정(예: 유 통업체 통제)에 강한 영향을 미친다고 주장하 며, 환경구성요인으로 이질성/동질성, 불안정성 /안정성, 분산성/집중성, 혼란성/평온성, 빈약성 /풍부성의 다섯 가지 차원을 제시하였다. 후속 연구에서 Achrol and Stern(1988)은 유통경로 시스템의 의사결정 불확실성에 영향을 미치는 환경요인으로 동태성, 다양성, 집중성, 풍요성, 그리고 상호연결성으로 재구분하였다. 그 중 가 장 영향력이 큰 요인들은 동태성과 풍요성으로 환경의 풍요성은 의사결정 불확실성을 감소시 켰으나. 반면에 동태성은 의사결정 불확실성을 증가시키는 것을 실증적으로 보여주었다.

산업재 물류에서의 환경 불확실성은 주로 다 
양성이라는 환경의 이질성과 가변성이라는 환경 의 역동성으로 나타난다(cf. Dahlstrom, McNeilly, and Speh 1996: McGinnis and Kohn 1993). 산업재 파트너간의 거래에 영향을 미치는 물류 환경요인들이 자주 변화하고 이들 간의 상호연 계가 급격히 증가 또는 감소함으로써 산업재 구매자가 불안정하고 단속적인 외부변화에 직 면할 때 물류환경의 가변성은 증가한다.

또한 물류환경의 다양성은 불확실성을 야기하 는 원천이 얼마나 많이 있는지를 나타낸다. 다 양한 물류환경에 노출된 산업재 구매기업은 내 부적으로 통합된 납품업체를 선택하기보다는 독립적인 공급업체를 선택함으로써 세분화되고 다양한 시장수요에 대응하고 또한 제 3자 전문 물류기업을 이용함으로써 자재공급의 유연성을 도모할 것이다.

\section{2 물류자원역량}

\subsection{1 자원준거이론과 물류자원역량}

자원준거이론(resource-based theory)의 본질 은 기업을 제품시장에서의 활동에 의해서가 아 니라 유·무형의 자원들의 독특한 결합체로서 파 악하는데 있다. 특히 기업의 자원을 요소시장에 서 획득가능한 것으로 보는 경제학적 관점과는 달리, 자원준거이론은 기업 보유 자원의 근원적 인 이동불가능성을 강조하고 기업내부의 특유 한 자원을 경쟁우위의 원천으로 보는 견해이다 (Bamey 1991; Prahalad and Hamel 1990; Wernerfelt 1984). 예를 들어, Wernerfelt(1984) 는 기업을 자원의 묶음(bundles of resources)으 로 정의하면서 기업의 자원은 유형 또는 비유
형적으로 분류할 수 있고 시장에서 획득되거나 기업내부에서 개발될 수 있다고 보았다. 또한 Bamey(1991)는 산업의 특성보다는 기업특유의 자원과 능력이 성과에 대한 설명력이 더 크다 는 기존 연구결과들을 지적하면서 경영자들이 어떻게 자원의 포토폴리오를 형성하며 지속적 경쟁우위의 원천이 되는 기업능력을 발전시켜 나가는가를 이해하는데 초점올 두는 연구가 필 요하다고 주장하였다.

Barney(1991)는 기업의 자원을 물리적 자산 (physical capital resources). 인적 자산(human capital resources), 조직 자산(organizational capital resources)으로 구분하였다. 자원준거이론에 의 하면 기업들은 이러한 자원들을 각자 특유 자 원으로 보유하며 특유 자원들의 결합에 의해 생성되는 기업능력이 경쟁우위의 원천이 된다 는 것이다(Prahalad and Hamel 1990).

물류에 있어서도 자원준거이론에 입각한 연구 자들은 기업특유의 역량을 개발하기 위한 기업 내부자원의 분석예 초점을 두고 있다(Olavarrieta and Ellinger 1997). 탁월한 물류성과는 경쟁적 이고 독특한 일련의 물류역량을 개발하고 그것 들을 전략적으로 잘 활용함으로써 창출된다는 것이다. Olavarrieta and Ellinger(1997)는 물류 자원 및 능력을 물류역량으로 제시하였다. 또한 Zhao, Droge, and Stank(2001)는 물류역량을 고객중심 역량과 정보중심 역량으로 구분하여 물류역량이 성과에 미치는 영향을 알아보았다.

본 연구에서는 자원준거이론에서 제시하는 물 리적 자산과 조직 자산에 초점을 두어 살펴보 고자 한다. 인적 자산은 기업의 물류인력의 우 수성, 지적 네트워크 등을 보아야하는데 자료의 한계상 제외하기로 한다. 물류자원역량의 구성 
요소를 조직 자산 측면에서는 물류정보화를 대 리변수(proxy)로 하여 살펴보고, 물리적 자산 측면에서는 물류자원을 proxy로 하여 논의하 고자 한다. 첫째, 물류정보화는 물류에서 $\mathrm{SCM}$ 이 가능하게 되는 핵심적 요소이다. 여기서 물 류정보화는 하드웨어적인 물류정보시스템(LIS: logistics information systems)의 정도를 의미한 다. IT를 기반으로 하는 물류정보시스템은 물류 관리 활동들의 효과적인 연계를 가능하게 하고 물류활동의 효율성을 높여 물류성과의 개선 및 기업경쟁력을 강화시킨다. $\mathrm{RFID}, \mathrm{EDI}$ 등은 물 류정보시스템이 업무 프로세스의 혁신 및 공 급사슬의 성과를 개선시킬 수 있는 수단들이 다(노승혁 외 2003; Droge and Germain 2000; Jayaram, Vickery, and Droge 2000), 예를 들 어, 물류정보시스템은 유통업에서 영업실적의 관 리를 용이하게 하고 또한 배송차량의 수송계획 및 경로선정을 용이하게 함으로써 공급사슬관리 의 효율성과 투명성을 향상시킨다. 뿐만 아니라 신속한 물류정보의 검색과 분석은 정확한 의사 결정이 가능하도록 하기 때문에 물류정보기술의 활용은 감량물류(lean logistics)를 실현할 수 있 는 필수적인 요소이다. 이러한 관점에서 물류정 보화 정도는 산업재 물류에서 거래기업들의 물 류경쟁력을 제고할 수 있는 중요한 요인이며, 산 업재 구매자가 제 3 자 물류나 물류활동의 외주 화(outsourcing)를 결정하는 중요한 척도이다.

둘째, 물류자원은 크게 세 가지 범주 즉 본원 적 자원(primary resources), 물류자산(assets), 물류능력(competence)을 포함한다. 본원적 자 원은 기본 설비인 지게차, 자재창고의 적치대, 기타 물류공구 등을 지칭하며, 물류자산은 특정 거래를 목적으로 기업이 투자했거나 통제할 수
있는 것 예컨데, 물류창고, 수송차량들, EDI, 인 공위성을 이용한 GPS, GIS 등을 말한다. 물류 능력은 물류자원을 활용하여 축적된 지식과 자 산으로 개별적인 물류지식과 스킬의 종합적인 묶음을 지칭한다.

본 연구에서도 선행연구들(cf. Olavarrieta and Ellinger 1997: Droge and Germain 2000: Stock and Lambert 2004)처럼 물류자원역량인 물류 정보시스템과 물류특유자산을 효율적으로 이용 하여 정시배송과 수송서비스의 일관성 등을 제 공하여야 기업의 물류성과도 높아진다는 논리 를 가정한다.

\section{3 관계규범과 물류서비스}

\section{3 .1 관계규범}

산업재 구매와 같이 시간의 경과에 따라 일련 의 거래에서 발생하는 이익과 부담을 공유하거나 또는 조정해야 하는 관계적 거래에서는 관계규범 이 구매자와 판매자간의 연결끈이 된다. 산업재 구매에서 물류관련 당사자들은 물류서비스의 복 잡성, 무형성 등으로 인해 불확실성에 직면한다. 이런 불확실성은 불규칙한 배달 등의 물류서비스 의 실패와 부정적인 물류성과로 이어지기 때문에 구매자와 공급자간에 관계규범이 필요하게 된다. 관계규범은 거래의 안전장치 역할을 함으로써 구 매자와 자재공급자간의 거래관계를 지속시킨다.

관계규범이란 거래관계를 맺고 있는 구매자 와 공급업자간에 암묵적으로 수용하는 행동의 규칙 또는 상대방 행위에 대한 기대라고 할 수 있다(Macneil 1980). 관계규범에 대한 연구 는 많은 학자들(Macneil 1980; Kaufmann and 
Stern 1988; Dahlstrom et al.1996)에 의해 이 루어졌다. 예를 들면 Macneil(1980)은 관계규 범을 정보교환(information exchange), 유연성 (flexibility), 결속력(solidarity)으로 설명하였고, Kaufmann and Stern(1988)은 역할보전(role integrity)과 상호성으로 관계규범을 규정하 였다. 본 연구에서는 선행연구(Macneil 1980: Dahlstrom et al. 1996: Lusch and Brown 1996) 를 바탕으로 관계규범을 산업재 물류에서의 정 보교환과 유연성으로 보고자 한다. 결속력을 고 려하지 않은 이유는 학자(cf. Heide and John 1992)에 따라서는 결속력을 행위변수들의 최종 결과인 몰입(commitment) 과 동일시하는 경향이 있어 여기서는 관계규범에서 제외하기로 한다.

정보교환은 산업재 구매기업과 자재 공급업체 간에 물류시스템운영과 물류활동 등에 관한 중 요한 자료를 공개하고 서로 주고받는 것을 말 한다. 정보교환은 교환파트너에게 도움이 되는 정보를 먼저 솔선수범하여 제공하고자 하는 의 지를 반영한다.

또한 산업재 물류에서 유연성 또는 운영 유연 성은 환경이 변화할 때 상호 우호적으로 정책 이나 전략을 변경할 수 있는 정도를 말한다. 즉 물류환경의 변화가 발생했을 때 거래일방이 갑 작스럽게 방침을 수정하여 상대방에게 해를 끼 치지 않을 것이라는 파트너의 기대이다.

\section{3 .2 물류서비스}

물류활동의 결과인 물류서비스는 학자들에 의해 다양하게 정의되고 있지만 가장 일반적인 것은 Perreault and Russ(1974)의 정의이다. Perreault and Russ에 의하면 물류서비스는 공
급자가 구매자에게 시간과 장소효용을 제공하 고 형태효용을 보장하기 위해 제공하는 일련의 상호 연관된 활동들을 말한다.

물류서비스의 연구흐름은 크게 두 단계로 분 류할 수 있는데, 초창기의 물류서비스는 물류고 객서비스의 요인을 파악하는데 치중하였다. 대 표적 초기 연구로 LaLonde and Zinszer(1976) 는 물류서비스를 구매 전 요인, 구매상황, 구매 후 요인으로 구분하였다. 그 후 LaLonde(1985) 는 물류서비스를 제품이용가능성, 주문주기시 간, 신뢰성, 대응소요시간, 실수율, 졔품출하 관 련 사고, 특별취급 등을 주요 요인으로 제시하 였다. 또한 Gilmore et al.(1994)은 Perrault and Russ(1974)가 제시한 17개 요소를 중요도에 따 라 제품의 이용가능성, $\mathrm{A} / \mathrm{S}$ 및 지원, 배송신뢰 도, 배송시간, 효율적 주문처리, 주문 편리성, 판매원의 기술적 능력, 제품성능 시연, 서류 이 용편의성 등의 물류서비스 요인을 추출하였다.

진일보된 물류서비스에 대한 연구는 $\mathrm{PZB}$ 의 서 비스품질(SERVQUAL) 개념을 도입하여 Mentzer 와 그의 동료들에 의해 지속적으로 발전되어 왔 다. Mentzer, Gomes, and Krafel(1989)는 기존 의 물류서비스 요소인 제품이용가능성과 적시 성에 배송품질을 추가하였다. 또한 일련의 논문 들(Mentzer. Flint, and Kent 1999; Mentzer, Flint, and Hult 2001)은 이를 발전시켜 제품가 용성, 정보품질, 적시성, 주문조건, 주문접수절 차, 배달정확성, 배달신뢰성, 불만처리 및 인적 접촉품질 등을 이용하여 물류서비스 품질(LSQ; Logistics Service Quality) 척도를 만들었고, 이 를 이용해 세분시장들의 물류서비스 품질 지각 차이에 맞추어 차별적 고객맞춤형 전략 실행을 제시하였다. 


\section{4 물류성과}

물류우량기업의 주요 특징으로 정교화된 물류 성과 측정 시스템의 구축을 들 수 있다(Bowersox et al. 1992: Bowersox et al. 1999). 바랍직한 성 과측정치는 기업의 가치를 높여주는 동시에 물류 관리자가 활동동인을 파악함으로써 원가우위와 서비스 차별화를 동시에 달성할 수 있도록 한다. 따라서 물류기업이 공급사슬 기업간 원가우위 달 성과 물류프로세스를 효율적으로 구축하기 위해 서는 정확한 물류성과 측정치가 필요하다.

물류성과는 물류활동의 최종결과물로 기업성 과를 항상시킨다(Bowersox et al. 1992; Sterling and Lambert 1989). 그러므로 물류기업의 성과 를 제고하기 위하여 물류성과에 영항을 미치는 물류 활동요인을 분석하는 것이 필수적이다. 물 류성과를 측정할 때 각 물류차원들의 특성과 기업 목적, 전략 방향 등의 상황을 감안하여 가
장 적합하고 구체적인 형태로 성과측정을 해야 할 것이다.

물류성과에 대한 대표적인 연구로 언급되는 Bowersox와 그의 동료들(1992)에 의하면 물류 우량기업은 성과측정을 지속적으로 실시한다는 것이다. 물류성과측정은 내부 물류성과측정과 외부 물류성과측정으로 구분될 수 있다. 내부 물류성과는 총물류비용, 직능별 비용, 자산관리, 고객서비스 성과, 피드백, 생산성, 물류품질의 등의 항목으로 측정되고, 외부 물류성과는 경쟁 사가 자사와 비교하여 어떻게, 얼마나 잘 하고 있는가를 벤치마킹하는 물류요소와 물류전략활 동으로 측정된다. 물류우량기업들은 내부성과 측정지표와 외부성과 측정지표를 물류 비우량 기업보다 횔씬 더 광범위하게 사용하고 있음을 Bowersox et al.(1992)은 보여 주었다. 물류성과 의 측정에 관한 중요 연구들을 요약하면 〈표 1〉 로 나타낼 수 있다.

〈표 1〉물류성과 측정에 관한 중요 연구 요약

\begin{tabular}{|c|c|c|c|}
\hline 연 구 자 & \multicolumn{3}{|c|}{ 측정 기준 } \\
\hline Bowersox et al.(1999) & $\begin{array}{l}\text { · 고객 통합 } \\
\text { · 기술 \& 계획 통합 }\end{array}$ & $\begin{array}{l}\text { · 내부 통합 } \\
\text { · 측정 통합 }\end{array}$ & $\begin{array}{l}\text { - 자재/서비스 공급업체 통합 } \\
\text { - 관계 통합 }\end{array}$ \\
\hline Shama, Grewal, and Levy(1995) & $\begin{array}{l}\text { · 제품가용성 } \\
\text { ·수·발추 처리 }\end{array}$ & $\begin{array}{l}\text { · 판매후 서비스 } \\
\text { · 배송시간 }\end{array}$ & · 물류 커뮤니케이션 \\
\hline Bowersox et al.(1992) & $\begin{array}{l}\text { · 총물류비용 } \\
\text { · 서비스 성과 } \\
\text { · 물류품질 }\end{array}$ & $\begin{array}{l}\text { · 직능별 비용 } \\
\text { · 피드백 }\end{array}$ & $\begin{array}{l}\text { - 자산관리 } \\
\text { - 생산성 }\end{array}$ \\
\hline Bowersox et al.(1989) & $\begin{array}{l}\text { · 자산관리 } \\
\cdot \text { · 고객서비스 } \\
\end{array}$ & $\begin{array}{l}\text { ·물류비용 } \\
\text { ·물류품질 }\end{array}$ & - 생산성 \\
\hline $\begin{array}{l}\text { Stock and Lambert(2004) } \\
\text { Sterling and Lambert(1989) }\end{array}$ & $\begin{array}{l}\text { · 고객서비스 수준 } \\
\text { · 총물류비용 (수송비, }\end{array}$ & 고비, 주문처리비, & 귀당 비용, 재고유지비) \\
\hline Shapiro(1984) & · 원가절감 지표 & ·차별화전랴 지 & \\
\hline LaLonde and Zinszer(1976) & $\begin{array}{l}\text { - 고객만족도 } \\
\text { - 이월주문량 }\end{array}$ & · 품절 & · 즉시배달 \\
\hline
\end{tabular}




\section{III. 연구모형 및 연구가설}

\section{1 연구 모형}

본 연구의 주된 관심은 국내 대기업 중 특히 제조업체와 거래하고 있는 기업들간의 물류분 야에 대한 연구를 통하여 산업재구매에서 물류 환경 불확실성과 물류자원역량이 물류서비스와 관계규범을 통하여 물류성과에 미치는 영향요 인을 규명하는데 있다. 연구 문제를 구체적으로 살퍼보면 첫째, 물류환경특성이 물류서비스와 관계규범에 영향을 미치는가? 둘째, 물류정보화 와 물류자원의 물류자원역량이 물류서비스와 관계규범에 영향을 주는가? 셋째, 산업재 구매 자와 공급업체간의 관계규범이 물류서비스의 향상에 영향을 미치는가? 넷째, 산업재 구매자 와 공급업체간의 관계규범이 물류성과에 직접 적으로 영향을 주는가? 다섯째, 물류서비스 수 준이 높을 때 물류성과도 향상되는가? 로 나타 낼 수 있다. 이러한 연구문제들을 정리하면 〈그 립 1)로 나타낼 수 있다.

\section{2 연구 가설}

\subsection{1 물류환경 불확실성, 관계규범 및 물류 서비스의 관계}

산업재 물류에서 구매자가 지각하는 시장환경 의 불확실성은 공급관련 정보의 불예측성에 있 다. 기업의 물류관련 의사결정과정에서 자재수 급, 납품경쟁정도, 납품업체의 물류능력. 자재품 목별 경쟁구조 등의 거래정보가 부족할 때 환 경불확실성이 높다고 할 수 있다. 이러한 시장 환경 불확실성은 구매자와 공급자간의 거래관 계를 발전시키는 계기가 된다. 외부 시장환경이 불확실할 때 산업재 구매자는 장기적으로 거래 할 수 있는 공급업체가 필요하고 공급업체들과 긴밀한 유대관계를 맺어 놓아야 기업에 필요 한 자재 및 물류서비스를 안정적으로 공급받을 수 있다(McGinnis and Kohn 1993; Droge and Germain 2000).

산업재 물류에서의 환경 불확실성은 주로 다 양성이라는 환경의 이질성과 가변성이라는 환 경의 역동성으로 나타난다. 산업재 구매자는 환

〈그림 1〉 개념적 연구모형

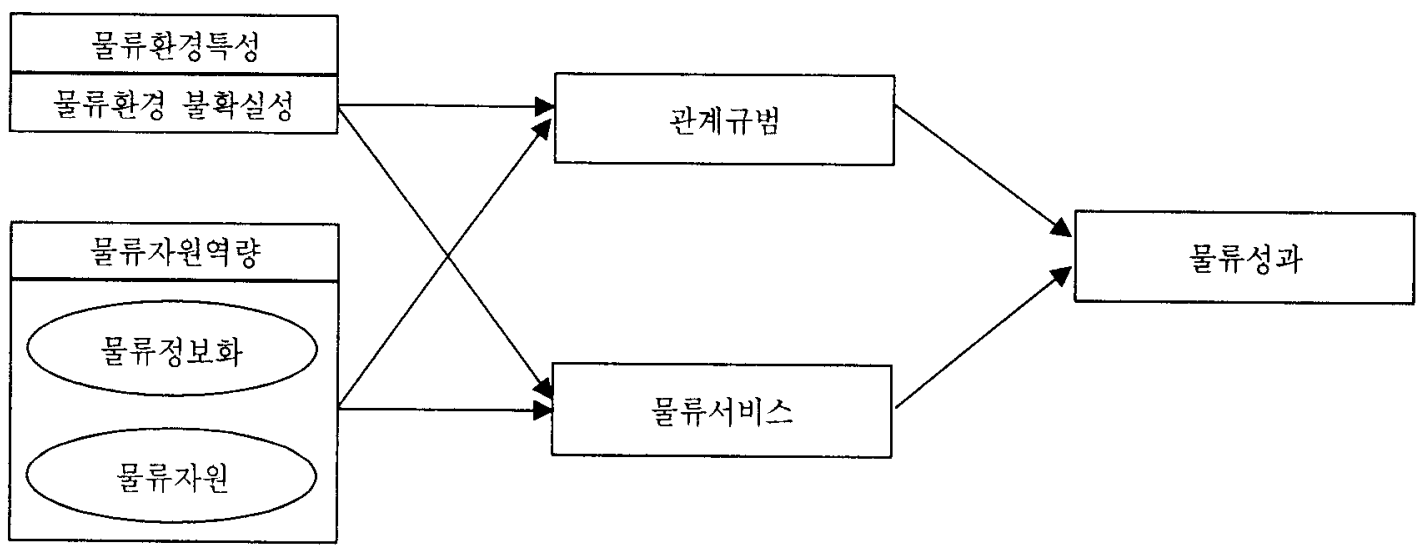


경의 가변성과 다양성이 높을수록 안정적으로 자재를 제공해 줄 수 있는 공급업체가 필요하 고, 공급업체도 구매시장 환경의 불확실성이 높 을 때 보다 적극적으로 물류서비스를 강화할 것이다(Droge and Germain 2000). 예를 들어, 산업재 구매자의 다양한 발주자재 및 서비스의 중요도 또는 긴급성의 정도에 따라 공급업체의 배송서비스가 맞춰져야함에도 불구하고 공급업 체들이 적절하게 대응하지 못한다면 구매자는 안정되고 유연한 배송서비스를 제공할 수 있는 공급업체와 거래를 할 것이다. 또한 물류관련 기술변화의 속도가 빠르거나 또는 최종소비자 의 수요가 불규칙하여 구매자의 발주량이 가변 적일 때 산업재 구매자는 일관성있는 물류서비 스를 공급업체에게 원할 것이다. 따라서 산업재 구매자는 물류환경의 가변성과 다양성이 높아 질 때 안정성과 유연성을 확보하기 위하여 적 정 재고수준이나 정시배송 등의 물류서비스를 보다 강하게 공급업체들에게 요구할 것이다. 따 라서 다음과 같은 가설을 설정할 수 있다.

가설 1: 산업재 구매에서 물류환경의 불확실 성이 높을수록 물류서비스 수준이 높아질 것이다.

관계규범은 환경변화에 따른 거래관계에서 어 느 한쪽이 갑작스럽게 계약방침을 파기하거나 수정하여 다른 일방에게 해를 끼치지 않을 것 이라는 거래파트너의 믿음정도로 볼 수 있다. 관계규범은 특히 시스템 또는 총체적 관계의 유지를 위한 행동을 규정하며, 당사자들의 개별 적 목표추구의 행동을 억제한다는 속성을 갖고 있기 때문에 의사결정권의 남용에 대한 보호장
치로서의 역할도 갖는다(Heide and John 1992). 자재가격이나 공급량이 불완전하거나 물류기 술변화의 속도가 빨라 물류환경의 가변성이 높 고. 거래의 불확실성을 유발시키는 이질적인 다 양한 원천이 존재할 때 산업재 구매자는 안정 적으로 제품을 공급해 줄 수 있는 공급업자와 관계규범을 형성하여 안정적인 거래를 하게 된 다. 예를 들어, 물류환경의 급격한 변화로 불확 실성이 높아질 때 산업재 구매기업은 거래의 효율성을 높이기 위하여 자재 공급업체에게 물 류시스템운영과 물류활동 등에 관한 중요한 자 료를 공개하고 상호 도움이 되는 정보를 교환 한다. 또한 산업재 구매자와 공급업체는 물류환 경이 변화할 때 거래일방이 갑작스럽게 방침을 수정하여 상대방에게 피해를 주지 않도록 상호 우호적으로 정책이나 전랴을 변경하는 운영의 유연성을 발휘하여 거래의 안정성을 기한다. 즉 물류환경의 불확실성이 커질 때 거래파트너간 의 정보교환, 거래 유연성 등의 관계규범이 더 요구된다. 따라서 다음과 같은 가설을 설정할 수 있다.

가설 2: 산업재 구매에서 물류환경의 불확실 성이 높을수록 관계규범 수준이 높 아질 것이다.

\subsection{2 물류자원역량, 관계규범 및 물류서비스의 관계}

본 논문에서 물류자원역량은 물류정보화와 물 류자원으로 이루어진다. 앞에서 언급했듯이 물 류정보화는 하드웨어적인 물류정보시스템(LIS) 의 정도를 나타내고 이는 물류역량의 중요구성 
요인이다(Zhao et al. 2001). 정보기술의 발달에 힘입어 LIS는 재고를 정보로 대체하는 효과를 통한 물류비용 절감효과와 아울러 신속한 주문 처리, 화물위치의 파악 등 실시간으로 물류정보 서비스를 교환하는 수단으로 각광받고 있다. 이 러한 LIS를 통한 물류거래는 최신 물류정보를 실시간으로 적절한 장소에 전달하는 적시성의 물류서비스를 제공한다. 예를 들어. 산업재 물 류에서 구매자인 제조업체가 생산일정과 재고 수준을 결정하기 위해서는 최종수요자의 주문 량 뿐만 아니라 납품업체의 리드타임과 배송시 기 등의 물류정보를 필요로 한다. 이러한 물류 관련 정보의 실시간 교환을 통하여 재고가용성 (Droge and Germain 2000), 적시성 등의 물류 서비스를 높일 수 있다. 따라서 다음과 같은 가 설을 설정할 수 있다.

가설 3: 산업재 구매에서 물류정보화 수준이 높을수록 물류서비스 수준이 높아질 것이다.

또한 물류정보화는 물류에서 SCM을 가능하 게 하는 핵심적 요소이다. IT를 기반으로 하는 물류정보시스템은 물류관리 활동들의 효과적인 연계를 가능하게 하고 $\mathrm{SCM}$ 구성원 상호간의 물류활동의 효율성을 높인다. 그러나 LIS가 물 류관리에 있어서 혁신적인 공헌을 하고 있음에 도 불구하고 거래기업간 배송지연, 납품수량의 오류발생. 잘못된 배송, 인도주기의 차질 등 물 류관련 사고가 종종 발생됨에 따라 배송의 질 이 떨어지고 있다. 이러한 단점은 LIS의 문제 라기보다는 거래당사자간의 관계규범의 문제라 고 할 수 있다. 물류정보시스템은 물류정보교환
에 혁신을 가져왔지만 거래정보의 신뢰성을 확 보하기 위해서는 관계규범이 절대적으로 필요 하다.

관계규범은 높은 물류정보수준의 확실성을 암 묵적으로 뒷받침하는 것이기 때문에 거래상대방 에게 미래보상에 대한 확신을 심어주는 것이 가 능하다. 잘 구축된 물류정보시스템과 물류 정보 화는 거래상호간의 원활한 물류정보교환과 돌발 적인 환경변화에 유연하게 적응할 수 있게 한 다. 따라서 다음과 같은 가설을 설정할 수 있다.

$$
\begin{gathered}
\text { 가설 4: 산업재 구매에서 물류정보화 수준이 } \\
\text { 높을수록 관계규범 수준이 높아질 } \\
\text { 것이다. }
\end{gathered}
$$

물류자원은 파트너와의 거래를 효율적으로 수행할 수 있는 물류특유자산 등의 물류시스템 과 물류지식이나 스킬 등의 물류능력을 말한다 (Olavarrieta and Ellinger 1997). 산업재 물류에 서 물류자원은 주로 발주처가 주문한 제품을 필요한 장소까지 이동시키는 수송서비스 능력 을 의미한다. 수송능력은 공급업체가 보유한 수송차량 및 하역장비 그리고 제품을 운송할 수 있는 경헙을 갖춘 유능한 수송인력을 지칭 한다. 뿐만 아니라 공급업체는 제품을 적재 및 하역할 수 있는 전문 노하우 능력을 갖추고 있 어야 한다. 이러한 수송서비스는 공간 또는 거 리를 초월하여 산업자재에 대하여 시간 및 장 소효용을 창출한다. 물류자원역량은 한 지점에 서 다른 장소로 자재를 얼마나 신속하고 일관 성 있게 산업자재를 이동시키는가를 결정하는 것이다(Stock and Lambert 2004). 산업재 구 매기업은 주문한 제품 또는 자재를 가능한 신 
속하고 정확하게 배송받기를 원하기 때문에 물 류자원능력은 물류서비스에 직접적인 영향을 미치게 된다. 따라서 다음과 같은 가설을 설정 할 수 있다.

가설 5: 산업재 구매에서 물류자원이 우수할 수록 물류서비스 수준이 높아질 것 이다.

산업재 구매기업이 일관성 있는 수송서비스를 제공받기 위해서는 수·배송상황에 대한 정보 교환과 운영유연성이 필요하다. 이러한 관계규 범이 보장되기 위해서는 산업재 거래기업들의 물류자원능력이 먼저 갖추어져야 한다. 우수한 물류자원능력 즉 첨단 수송설비시스템, 물류센 터 등의 물류특유자산과 수·배송 물류노하우 등을 잘 활용한다면 원활한 물류정보 교환, 돌 발적 환경변화에의 유연한 적응 등의 관계규범 수준이 높아질 것이다.

반면에 물류자원능력이 우수한 거래기업들 이 환경 불확실성이 높아질 경우 자사의 이익 을 위한 기회주의적 행위를 할 가능성이 있고 이 때 정보교환, 운영유연성 등의 관계규범 수 준은 오히려 떨어질 수도 있다. 본 논문에서는 전자의 논리를 따라 다음과 같은 가설을 설정 하였다.

가설 6: 산업재 구매에서 물류자원이 우수할수 록 관계규범 수준이 높아질 것이다.

산업재 구매에서 발주처와 공급업체간에 이루 어지는 실무적인 물적교환은 계약을 통하여 명 시적 거래형태를 띠는 경우가 일반적이다. 그러
나 거래가 일정기간 지속됨에 따라 이익과 부 담을 조정하는 수단으로서 관계규범이 형성된 다. 이러한 관계규범은 상호간의 원할한 정보교 환, 운영유연성 등으로 높은 수준의 물류정보를 자발적으로 교환하는 매개역할을 한다.분만 아 니라 관계규범은 일탈적인 행동에 대한 보호장 치로서 암묵적인 합의를 통하여 순기능적 역할 을 하여 물류서비스를 향상시키는 것으로 볼 수 있다.

산업재 물류에서 구매자인 제조업체가 생산일 정과 재고수준을 결정하기 위해서는 고객의 수 요량뿐만 아니라 공급업체의 리드타임과 배송 시기 등 물류정보를 필요로 한다. 이에 실시간 의 물류정보 교환을 통하여 배송의 질, 적시성 등의 물류서비스를 높일 수 있다.

또한 정보공유는 상대적으로 민감하고 독점적 인 물류정보를 서로 교환하는 것이기 때문에 기회주의적 행동이나 도덕적 해이 등이 발생하 지 않도록 거래상대방에게 미래보상에 대한 확 신을 심어주는 것이 필요하다. 잘 구축된 물류 정보시스템을 이용하여 물류정보의 원활한 공 유, 돌발적인 환경변화에 대한 유연한 적응 등 의 관계규범이 형성되면, 이러한 관계규범은 기 회주의적 행동 가능성을 줄이고 미래보상에 대 한 확신을 배양하여 정시배송과 일관성 있는 수 송서비스 등의 양질의 물류서비스를 제공할 수 있게 할 것이다(Closs et al. 2005: Dahlstrom et al. 1996). 따라서 다음과 같은 가설을 설정할 수 있다.

가설 7: 산업재 구매에서 운영유연성. 정보교 환 등의 관계규범 수준이 높을수록 물류서비스 수준이 높아질 것이다. 
3.2 .3 관계규범, 물류서비스 및 물류성과의 관계 거래당사자간에 합의된 관계규범은 물류성과 에 영향을 미침으로써 기업성과를 향상시킨다 (Dahlstrom et al. 1996: Sterling and Lambert 1989). 그러므로 물류기업의 성과를 제고하기 위하여 관계규범이 물류성과에 주는 영향을 알 아보는 일은 의미있는 일이다. 거래관계가 진전 되어 거래파트너들이 상당한 물류거래 특유투 자를 하게 되었을 때 산업재 구매자와 공급업 체간의 원활한 정보교환, 운영유연성 등의 관계 규범의 형성은 거래의 확실성과 안전성을 높여 주는 기능을 하게 되고 이러한 역할은 기업의 물류성과를 향상하는데 도움을 준다(Dahstrom et al. 1996). 예를 들어, 운송비용, 보충리드타 임 등에 대한 정보가 왜곡되면 수·배송자원의 비효율성으로 인해 물류비용이 증가하여 수익성 이 감소할 것이다. 또한 배송의 긴급성이 요구 되는 경우나 품절시 다른 공급업체의 물류센터 를 이용하여 자재를 신속히 배송하는 등의 운영 의 유연성이 발휘된다면 이는 기업간의 협력적 거래 분위기를 조성하여 물류성과를 높일 것이 다. 따라서 다음과 같은 가설을 설정할 수 있다.

가설 8: 산업재 구매에서 거래기업간 관계규 범 수준이 높을수록 물류성과가 높 아질 것이다.

물류서비스는 물류활동의 결과로서 공급업체 와 발주처 사이의 제품과 서비스의 이동을 통해 고객에게 시간효용과 장소효용을 제공 함으로써 물류성과를 제고한다(Mentzer et al. 1989; Sterling and Lambert 1989: Stock and Lambert 2004). 예를 들어. Sterling and Lambert
(1989)는 제품, 가격, 판매촉진, 물류 등의 마케 팅 믹스 요소들은 시장성과에 동일하게 영향을 미치지 않는다는 것을 밝히면서 그 중 제일 중 요한 요인은 물류서비스임을 보여주었다.

여기서 우리가 암묵적으로 가정하고 있는 것 은 물류서비스 증가는 물류성과를 제고하고 이 는 궁극적으로 기업성과를 향상시킨다는 것이 다. 전달영, 정창환(1997)은 물류서비스와 상표 력의 상대적 영향력 비교를 통하여 물류서비스 가 시장점유율에 더 큰 영향을 주는 것을 보여 주었고, Daugherty et al.(1998)도 물류서비스가 고객만족과 애호도를 통하여 시장점유율에 유 의적인 영향을 주는 것을 실증하였다.

특히 산업재 물류에서는 산업재 납품업체가 발주처가 주문한 제품을 적시에 배송하고 또 고객이 원할 때 즉시 이를 수용할 수 있는 제 품가용성이 물류서비스의 요체이다. 재고가용성 확대, 정시배송을 통한 물류서비스는 물류비용 절감과 리드타임 단축을 통한 배송의 질 향상 등의 물류성과를 가져온다. 따라서 다음과 같은 가설을 설정할 수 있다.

가설 9: 산업재 구매에서 물류서비스 수준 이 높을수록 물류성과가 높아질 것 이다.

\section{IV. 실증 분석}

\section{1 자료 수집}

본 연구의 자료는 우리 나라 중화학 기계공업 
의 대표적 요람인 창원공단의 $\mathrm{H}$ 중공업 및 $\mathrm{HSD}$ 엔진의 물류관련 구매담당자들이 자재납품 협력업체와의 거래에서 인식하는 물류관련 제 반개념 및 서비스에 관한 것이다. $\mathrm{H}$ 중공업은 정부의 국영기업 민영화 계획에 따라 정부소유 에서 DS그룹으로 민영화된 우리나라 중화학공 업의 대표적인 기업으로 주요 업종은 발전설비 및 플랜트설비를 생산하는 기업이다. 또한 HSD 엔진은 대형선박용 디젤엔진을 생산하는 엔진 전문 생산업체이다. $\mathrm{H}$ 중공업과 $\mathrm{HSD}$ 엔진을 연 구대상으로 한 주된 이유는 이들 두 기업의 물 류규모가 방대하고, 거래기업의 수가 많기 때문 에 상대적으로 비교적 물류환경 불확실성이 높 고, 물류자원역량이 많이 요구되기 때문이다. 또한 제품생산에서 요구되는 기술수준이 높고 거래품목이 다양할 뿐만 아니라 자재수급에서 적시성과 배송의 질이 제품생산에 중대한 영향 을 주기 때문에 물류서비스를 연구하기에 적당 하다고 판단되었다.

먼저 본 설문조사를 하기 전에 물류관련 핵심 담당자들과의 심층면접(in-depth interview)을 통하여 사전에 개발된 설문지를 현장에 맞게 수정 - 보완하였다. 연후에 물류관련부서에서 30 부의 설문지로 사전조사(pilot study)를 하여 설문지를 재수정하였다. 그 다음 $\mathrm{H}$ 중공업 및 $\mathrm{HSD}$ 엔진(주)의 물류관련부서(구매부, 자재관 리부, 수출입관리부, 외주관리부, 수입검사부)에 종사하는 사원부터 임원까지의 직원을 대상으 로 주 설문조사를 실시하였다. 설문에 참여한 핵 심 응답자(key informant)는 H중공업 및 $\mathrm{HSD}$ 엔진에서 물류업무를 담당하는 167 명이고, 각 핵심 응답자가 담당하는 자재납품업체 중에서 2 개 회사를 선정하여 구매자의 입장에서 납품
협력업체를 평가하게 하여 총 334 부의 설문지 를 배부하였다. 이 과정에서 각각의 핵심 응답 자가 평가하는 납품거래업체의 중복을 회피하 기 위한 방법으로 전체 납품업체명부를 토대로 부서별로 조사대상업체를 선정하여 평가업체를 지정해 주었다. 설문지는 미회수된 36 부를 제외 하고 총 298 부가 회수되었으나. 불성실한 응답 26 부를 제외하고 총 272 부가 자료분석에 이용 되었다.

\section{2 측정}

설문지는 물류환경특성, 물류정보화와 물류자 원 등의 물류자원역량, 물류서비스, 관계규범, 물류성과, 그리고 일반적 기업특성의 여섯 부문 으로 구성되었다. 인구통계학적 내용인 기업특 성은 명목척도로 측정되었고 나머지 구성개념 들은 7점 등간척도(1) 전혀 그렇지 않다 (7) 매우 그렇다)로 측정되었다.

물류환경의 불확실성은 McGinnis and Kohn (1993)과 Ganesan(1994)이 사용한 환경다양성 과 가변성을 참고하여 본 연구에 맞게 측정항 목을 개발하여 측정되었다. 예를 들어, 발주업 체가 인식하는 구매환경의 불확실성은 최종수 요자가 요구하는 자재수요가 다양하다, 자재구 매시장환경은 경쟁이 치열하고 빨리 변한다, 자 재구매시장은 새로운 납품업체들이 수시로 나 타나고 없어지는 과정이 되풀이된다, 발주처 자 재품목에 따라 독점, 과점, 완전경쟁 등 자재거 래 경쟁환경이 이질적이다 등의 항목들로 측정 되었다.

물류자원역량에서 물류정보화 정도는 노승혁 외 (2003)과 Zhao et al.(2001)을 참고하여 본 
연구에 맞게 측정항목을 개발하였다. 예를 들 어. 자재납품관련에 대한 정보교환을 $\mathrm{EDI}$ 를 이 용하여 한다, 발주처의 자재입찰에 대부분 전자 적 거래를 통하여 참여한다. 물류정보시스템 (LIS)을 이용하여 자재물류정보를 교환하고 있 다, 자재추적시스템을 구축하여 시간과 비용을 절감하고 있다 등의 항목으로 측정하였다. 또한 물류자원역량에서 물류자원은 Olavarrieta and Ellinger(1997)와 Stock and Lambert(2004)를 참고하여 납품업체는 적절한 수송차량 및 하역 장비를 확보하고 있다. 자재수송에 관한 경험을 갖춘 유능한 수송인력을 보유하고 있다. 납품업 체는 발주처가 필오로 하는 정확한 자재수요예 측, 배송루트 등의 물류지식을 보유하고 있다. 납품업체는 발주처가 필요로 하는 물류프로세 스, 포장 등에 대한 물류기술력을 보유하고 있 다 등의 항목으로 측정되었다.

물류서비스는 전달영, 정창환(1997). Mentzer et al.(1989), Sterling and Lambert(1989) 등 의 연구를 참고하여 재고가용성, 적시성을 물 류서비스의 핵심개념으로 보았다. 재고 가용성 은 보유재고가 품절되는 경우는 거의 없고 주 문보충율이 양호한 편이다. 일회적 자재주문량 이 소량이라도 주문이 용이하다, 고객의 긴급 주문에 대응할 수 있는 충분한 재고를 보유하 고 있다, 납품업체는 결손자재를 긴급히 보충 할 수 있는 자재 대체처리능력이 우수하다 등 의 항목으로 측정되었다. 또한 적시성은 고객 의 긴급주문수요를 신속하게 처리하는 편이다. 발주처의 자재납품요구에 대한 정시납품 준수 율이 높은 편이다. 발주처의 주문요구사항을 처리하는 시간이 빠르다. 납품업체는 우리 회 사가 요구하는 자재를 일관되게 적절한 기간
내에 배송하고 있다, 불합격품에 대한 반품처 리를 신속하게 회수조치한다 등의 항목으로 측 정되었다.

관계규범은 MacNeil(1980), Kaufmann and Stem(1988), Dahlstrom et al.(1996)의 연구를 근간으로 하여 정보교환과 유연성을 핵심개념 으로 보았다. 정보교환은 사전에 충분한 협의 및 자료를 공유한다, 여러 경로를 통하여 정보 교환을 하고 있다, 발주처와 납품업체는 중요한 거래정보 및 자료를 상호 공개하고 있다, 우리 기업은 납품업체의 물류담당자와 인간적인 교 류를 통해 다양한 정보공유를 하고 있다 등의 항목으로 측정되었다. 또한 유연성은 납품업체 와 발주처는 자재납품이 계약에 조금 위배되더 라도 상호 적절하게 처리한다, 발주처의 주문사 항이 수정된 경우 구매담당자의 긴급요구를 우 선 수용한다, 발주처가 요구하는 자재품목이 품 절될 때 납품업체는 제 삼자를 통해 자재조달 이 가능하도록 알선해준다 등의 항목으로 측정 되었다.

마지막으로, 물류성과는 김용철, 김재일(2001), Bowersox et al.(1992), Mentzer et al.(1989) 등의 연구를 근간으로 측정항목을 개발하였다. 예를 들어, 물류성과는 납품업체는 물류서비스 증가를 통하여 총물류비용을 감소시켰다. 납품 업체는 물류프로세스 개선을 통해 리드타임(납 기지연)을 현저히 감소시켰다. 납품자재의 손 상, 과부족 등의 자재문제발생이 줄어 들었다. 납품업체는 발주처가 주문한 자재납품에 대하 여 정확한 납품준수율을 이행하고 있다 등의 항목으로 측정되었다. 각 연구개념들에 대한 조 작적 정의와 측정항목들을 정리하면 〈표 2〉와 같다. 
〈표 2〉 연구개념에 관한 조작적 정의 및 측정항목

\begin{tabular}{|c|c|c|c|}
\hline & 조작적 정의 & 측정 항목 & 연구자 \\
\hline $\begin{array}{l}\text { 물류환경특성 } \\
\text { - 물류환경 } \\
\text { 불확실성 }\end{array}$ & $\begin{array}{l}\text { - 자재납품에서의 자재수요, 자 } \\
\text { 재종류, 경쟁 등의 거래환경 } \\
\text { 의 역동성, 다양성 정도 }\end{array}$ & $\begin{array}{l}\text { - 구매환경의 경쟁이 치열하고 빨리 } \\
\text { 변함, 납품업체의 잦은 교체, 자재 } \\
\text { 수요의 다양성, 자재 품목에 따른 } \\
\text { 경쟁환경의 이질성 등의 항목 }\end{array}$ & $\begin{array}{r}\text { McGinnis and } \\
\text { Kohn (1993); } \\
\text { Ganesan(1994) }\end{array}$ \\
\hline $\begin{array}{l}\text { 물류자원역량 } \\
\text { - 물류정보화 } \\
\text { - 물류자원 }\end{array}$ & $\begin{array}{l}\text { - 납품업체와의 물류정보시스 } \\
\text { 템을 통한 전자적 기래 정도 } \\
\text { - 납품업체의 수·배송 능력 } \\
\text { 과 납품업체의 물류자원 및 } \\
\text { 시스템에 대한 투자 정도 }\end{array}$ & $\begin{array}{l}\text { - EDI를 통한 거래, 전자적 거래 입 } \\
\text { 찰, LIS를 통한 물류정보교환, 자 } \\
\text { 재추적시스템의 활용 정도 등의 } \\
\text { 항목 } \\
\text { 수송차량. 하역장비의 보유, 유능 } \\
\text { 한 수송인력, 배송루트 등의 물류 } \\
\text { 지식. 물류 프로세스 등의 물류기 } \\
\text { 술력 등의 항목 }\end{array}$ & $\begin{array}{l}\text { 노승혁 외 2인(2003): } \\
\text { Zhao et al.(2001); } \\
\text { Olavarrieta and } \\
\quad \text { Ellinger(1997); } \\
\text { Stock and } \\
\text { Lambert(2004) }\end{array}$ \\
\hline $\begin{array}{l}\text { 물류서비스 } \\
\text { - 가용성 } \\
\text { - 적시성 }\end{array}$ & $\begin{array}{l}\text { - 납품업체의 재고보유 및 주 } \\
\text { 문처리 정도 } \\
\text { - 발주업체의 주문 및 요구사 } \\
\text { 항에 대한 납품업체의 적정 } \\
\text { 배송 정도 }\end{array}$ & $\begin{array}{l}\text { - 주문보충율, 주문용이성, 여분 재 } \\
\text { 고보유 정도, 주문완전충족율 등 } \\
\text { 의 항목 } \\
\text { - 배송의 일관성, 긴급주문의 신속 } \\
\text { 성, 주문요구사항의 처리시간, 반 } \\
\text { 품처리 등의 항목 }\end{array}$ & $\begin{array}{l}\text { 전달영, } \\
\text { 정창환(1997); } \\
\text { Mentzer, Gomes, and } \\
\text { Krapfel(1989); } \\
\text { Streling and } \\
\text { Lambert(1989) }\end{array}$ \\
\hline $\begin{array}{l}\text { 관계규범 } \\
\text { - 정보교환 } \\
\text { - 유연성 }\end{array}$ & $\begin{array}{l}\text { - 납품업체와의 정보교류 정도 } \\
\text { - 예상치 않은 상황 발생시 } \\
\text { 납품업체의 탄력적 주문처 } \\
\text { 리 정도 }\end{array}$ & $\begin{array}{l}\text { - 사전 업무헙의 및 자료공유, 물류 } \\
\text { 정보교환, 다양한 경로를 통한 정 } \\
\text { 보공유 등의 항목 } \\
\text { - 자재납품조건의 탄력적 운용, 긴 } \\
\text { 급요구수용 여부, 품절자재의 대 } \\
\text { 체처리 등의 항목 }\end{array}$ & $\begin{array}{l}\text { Macneil(1980): } \\
\text { Kaufmann and } \\
\text { Stern(1988); } \\
\text { Dahlstrom et } \\
\text { al.(1996) }\end{array}$ \\
\hline - 물류성과 & $\begin{array}{l}\text { - 납품업체와 발주업채의 물 } \\
\text { 류비용절감 및 배송품질의 } \\
\text { 질 향상 정도 }\end{array}$ & $\begin{array}{l}\text { - 물류비용감소 리드타임(납기지연) } \\
\text { 감소, 납품자재 손상, 과부족 등의 } \\
\text { 문제발생빈도 감소. 정확한 납품 } \\
\text { 준수율 향상 등의 항목 }\end{array}$ & $\begin{array}{l}\text { 김용철,김재일(2001); } \\
\text { Bowersox et al.(1992, } \\
\text { 1999); Mentzer et } \\
\text { al.(1989) }\end{array}$ \\
\hline
\end{tabular}

\section{3 분석 결과}

수집된 자료는 SPSS의 탐색적 요인분석, 신 뢰성분석과 LISREL의 구조방정식모형(structural equation modeling) 을 이용하여 분석되었다.

\subsection{1 자료 특성}

자료는 $\mathrm{H}$ 중공업 및 $\mathrm{HSD}$ 엔진의 물류관련부서 (구매부, 자재관리부, 수출입관리부, 외주관리 부, 수입검사부)에 종사하는 167 명의 핵심 응답 자로부터 수집하였다. 설문조사에 참여한 핵심 응답자 167 명의 인구통계학적 특성을 살펴보면 
다음과 같다.

재직기간은 1-3년이 3.3\%, 4 5년이 $16.5 \%$, 6 7년이 $34.2 \%$, 8년이상이 $46 \%$ 의 순으로 나 타나 6 년 이상 근무자가 $80.2 \%$ 로 응답자들이 물류관련업무에 상당한 경헙이 있음을 알 수 있어 자료의 내용타당성이 있음을 유추할 수 있다. 담당직무를 살펴보면 구매부서 $82.7 \%$, 자 재관리 $12.9 \%$, 창고관리 $2.9 \%$, 자재검수부서 $1.5 \%$ 순으로 분포되었으며. 현 직무담당기간은 1 2년이 17.3\%, 3-4년이 41.9\%, 5-6년이 $17.3 \%, 7$ 년이상 $23.5 \%$ 순으로 나타나 전반적으 로 현재의 물류관련업무에 숙련되었음을 알 수 있다. 또한 담당자재별로 구분해 보면, 금속철 강재류 $29.8 \%$, 원료자재류 $4.4 \%$, 부품자재류 $26.1 \%$, 일반자재류 $39.3 \%$ 순으로 나타났다. 핵 심응답자들이 지각하는 물류기능의 중요성 정 도는 '전혀 중요하지 않다' $3.3 \%$. '그저 그렇다' $3.3 \%$, '매우 중요하다' $93.4 \%$ 로 나타나 응답자 들이 물류기능의 중요성을 높게 인식하는 것으 로 나타났다. 마지막으로 연령분포를 보면 20대 $2.6 \%, 30$ 대 $75.7 \%, 40$ 대 $20.2 \%, 50$ 대 $1.5 \%$ 순 으로 나타나 물류관련부서에 근무하는 직원은 30,40 대가 주류를 이루고 있음을 알 수 있다. 종합적으로 보면 물류관리를 담당하는 직원은 대체적으로 물류업무에 숙련된 경력직으로 구 성되었음을 알 수 있다.

\subsection{2 척도 평가}

본 연구에서는 다항목 측정항목을 정제하고 척도의 신뢰성과 타당성을 확인하기 위하여 Anderson and Gerbing(1988)이 제안한 절차를 따랐다. 모든 척도에 대해 탐색적 요인분석과
Cronbach's $a$ 를 병행하여 신뢰성을 분석하였다. 신뢰성 계수 값이 어느 정도의 수준이어야 한 다고 절대적으로 규정하기는 어렵지만 일반적 으로 사용하는 Nunnally(1978)가 제안한 신뢰 도 0.6 이상을 기준으로 하였다. 또한 측정항목 들의 corrected item-total correlation 상관계수 의 값이 0.3 이하인 항목들은 모두 제거되었다. 요인추출 방법으로는 표본의 분산을 가장 많 이 설명해주는 주성분분석(principal component analysis)을 실시하였고, 해석상의 명확성과 추 가적인 분석에 활용하기 위해 직각회전방법 (varimax)을 이용하였다. 요인분석 결과의 평 가는 오인적재값 .5 이상, 아이겐 값 1.0 이상 기준으로 하였다(Hair, Anderson, Tatham, and Black 1998). 뿐만 아니라 확증요인분석을 이용 하여 연구모델에 적합한 측정항목을 찾기 위하 여 수정지수가 12 가 넘는 항목들은 제거되었다 (Hair et al. 1998). 이러한 정제과정을 통하여 최종적으로 남은 측정항목들의 요인적재량, 신뢰 도 및 요인부하랑들이 〈표 3〉에 정리되어 있다. 모든 요인의 신뢰성 계수가 $a=0.6667 \sim 0.8305$ 로 나타나 Nunnally(1978)가 제시한 0.60이상 기준을 상회하므로 가설검정에 충분한 신뢰성 을 갖는 것으로 평가된다.

척도의 집중타당성을 검토하기 위하여 전체 구성개넘에 대하여 LISREL 프로그램의 최우추 정(maximum likelihood estimation) 방법을 이용 하여 확증요인분석을 실시하였다. 〈표 3〉의 측 정모델에서 보듯이 요인부하량의 $\mathrm{t}$ 값이 $\mathrm{a}=.05$ 수준에서 모두 유의하므로 측정항목들의 집중 타당성이 있는 것으로 평가된다.

그리고 판별타당성을 알아보기 위해 구성개념간 상관관계행렬( $\Phi$ matrix)을 검토하였다(Anderson 
〈표 3〉 측정변수들에 대한 탐색적 요인분석. 신뢰도분석 및 타당성분석

\begin{tabular}{|c|c|c|c|c|c|c|}
\hline \multirow{2}{*}{\multicolumn{2}{|c|}{ 구성개념 및 측정항목 }} & \multicolumn{2}{|c|}{ 탐색적 요인분석 } & \multirow{2}{*}{ Cronbach's a } & \multicolumn{2}{|c|}{ 측정모델 } \\
\hline & & 요인적재량 & 아이겐 값 & & 요인부하량 & $\mathrm{t}$-value \\
\hline \multicolumn{2}{|c|}{$\begin{array}{l}\text { 물류환경 불확실성 } \\
\text { - 구매환경의 경쟁이 치열하고 빨리 변함 } \\
\text { - 자재수요의 다양성 }\end{array}$} & $\begin{array}{l}.925 \\
.925\end{array}$ & 1.710 & .8305 & $\begin{array}{l}1.000 \\
1.224\end{array}$ & $\begin{array}{c}- \\
5.047\end{array}$ \\
\hline \multicolumn{2}{|c|}{$\begin{array}{c}\text { 물류정보화 } \\
\text { - LIS를 통한 물류정보교환 } \\
\text { - 자재추적시스템의 활용 정도 }\end{array}$} & $\begin{array}{l}.899 \\
.899\end{array}$ & 1.618 & .7637 & $\begin{array}{l}1.000 \\
0.963\end{array}$ & $\begin{array}{c}- \\
7.355\end{array}$ \\
\hline \multicolumn{2}{|c|}{$\begin{array}{c}\text { 물류자원 } \\
\text { - 수송차량, 하역장비의 보유 } \\
\text { - 배송루트 등의 물류지식 }\end{array}$} & $\begin{array}{l}.887 \\
.887\end{array}$ & 1.574 & .7261 & $\begin{array}{l}1.000 \\
1.446\end{array}$ & 5.766 \\
\hline \multicolumn{2}{|c|}{$\begin{array}{l}\text { - 주룰류서보치충율 } \\
\text { - 주문용이성 } \\
\text { - 배송의 일관성 }\end{array}$} & $\begin{array}{l}.817 \\
.787 \\
.718 \\
\end{array}$ & 1.803 & .6667 & $\begin{array}{l}1.000 \\
0.940 \\
0.784 \\
\end{array}$ & $\begin{array}{c}- \\
8.383 \\
8.069\end{array}$ \\
\hline \multirow{2}{*}{$\begin{array}{l}\text { 관 } \\
\text { 계 } \\
\text { 규 } \\
\text { 범 }\end{array}$} & $\begin{array}{l}\text { 정보교환 } \\
\text { - 사전 업무협의 및 자료공유 } \\
\text { - 물류정보교환 } \\
\text { - 다양한 경로를 통한 정보공유 }\end{array}$ & $\begin{array}{l}.873 \\
.872 \\
.758 \\
\end{array}$ & 2.098 & .7808 & 1.000 & - \\
\hline & $\begin{array}{l}\text { 유연성 } \\
\text { - 자재납품조건의 탄력적 운용 } \\
\text { - 긴급요구수용여부 } \\
\text { - 품절자재의 대체처리 }\end{array}$ & $\begin{array}{l}.867 \\
.802 \\
.762 \\
\end{array}$ & 1.975 & .7298 & 1.066 & 8.446 \\
\hline \multicolumn{2}{|c|}{$\begin{array}{l}\text { 물류성과 } \\
\text { - 물류비용감소 } \\
\text { - 리드타임(납기지연) 감소 } \\
\text { - 정확한 납품준수율 향상 }\end{array}$} & $\begin{array}{l}.850 \\
.847 \\
.837\end{array}$ & 2.131 & .7959 & $\begin{array}{l}0.950 \\
1.000 \\
1.037\end{array}$ & $\begin{array}{c}10.019 \\
- \\
10.153\end{array}$ \\
\hline
\end{tabular}

and Gerbing 1988). (표 4〉의 상관관계표에서 보는 바와 같이 표준오차를 두 배하여 변수간 상관관계와 합한 결과 변수간 관계 모두에서 상관관계가 0.95 를 초과하지 않아 구성개념간 판별타당성이 있는 것으로 평가된다. 또한 각 연구개념의 구성개념 신뢰도와 분산추출값의 대부분이 권장기준치(구성개념 신뢰도 .7, 분산 추출값 .5) (Hair et al. 1998)보다 높거나 근접
해 측정항목들이 구성개념에 대한 대표성을 갖 고 있는 것으로 판단된다. 그러나 물류자원의 구성개념 신뢰도 $(0.52)$ 와 분산추출값(0.36)이 기 준보다 미흡하나 신뢰계수(0.7261)도 갠찮고 측정 모델에서 측정항목들의 요인부하량 $(\mathrm{t}$ 값 $=5.766)$ 이 유의하므로 집중타당성을 가지는 것으로 볼 수 있다. 
〈표 4〉 구성개념간 상관관계. 개념신뢰도 및 분산추출값

\begin{tabular}{|c|c|c|c|c|c|c|c|c|}
\hline \multirow[b]{2}{*}{ 척 도 } & \multicolumn{6}{|c|}{ 구성개념간 상관관계 } & \multirow{2}{*}{$\begin{array}{l}\text { 구성개념 } \\
\text { 신뢰도 }\end{array}$} & \multirow{2}{*}{$\begin{array}{l}\text { 분 산 } \\
\text { 추출값 }\end{array}$} \\
\hline & $\begin{array}{c}\text { 환경불확실성 } \\
\left(\xi_{1}\right)\end{array}$ & $\begin{array}{c}\text { 물류정보화 } \\
\left(\zeta_{2}\right)\end{array}$ & $\begin{array}{c}\text { 물류자원 } \\
\left(\xi_{3}\right)\end{array}$ & $\begin{array}{c}\text { 물류서비스 } \\
\left(\eta_{1}\right)\end{array}$ & $\begin{array}{c}\text { 관계규범 } \\
\left(\mathrm{n}_{2}\right)\end{array}$ & $\begin{array}{c}\text { 물류성과 } \\
\left(n_{3}\right)\end{array}$ & & \\
\hline $\begin{array}{c}\text { 환경불확실성 } \\
\left(\xi_{1}\right)\end{array}$ & 1.00 & & & & & & 0.84 & 0.73 \\
\hline $\begin{array}{c}\text { 물류정보화 } \\
\left(\xi_{2}\right)\end{array}$ & $\begin{array}{c}0.07 \\
(0.06)^{*}\end{array}$ & 1.00 & & & & & 0.66 & 0.50 \\
\hline $\begin{array}{c}\text { 물류자원 } \\
\left(\xi_{3}\right)\end{array}$ & $\begin{array}{c}0.13 \\
(0.07)\end{array}$ & $\begin{array}{c}0.41 \\
(0.10)\end{array}$ & 1.00 & & & & 0.52 & 0.36 \\
\hline $\begin{array}{c}\text { 물류서비스 } \\
\left(n_{1}\right)\end{array}$ & $\begin{array}{c}0.14 \\
(0.06)\end{array}$ & $\begin{array}{c}0.44 \\
(0.08)\end{array}$ & $\begin{array}{c}0.78 \\
(0.08)\end{array}$ & 1.00 & & & 0.73 & 0.48 \\
\hline $\begin{array}{c}\text { 관계규범 } \\
\left(\mathrm{n}_{2}\right)\end{array}$ & $\begin{array}{c}0.15 \\
(0.07)\end{array}$ & $\begin{array}{c}0.62 \\
(0.07)\end{array}$ & $\begin{array}{c}0.35 \\
(0.10)\end{array}$ & $\begin{array}{c}0.75 \\
(0.06)\end{array}$ & 1.00 & & 0.65 & 0.48 \\
\hline $\begin{array}{c}\text { 물류성과 } \\
\left(n_{33}\right)\end{array}$ & $\begin{array}{l}-0.14 \\
(0.06)\end{array}$ & $\begin{array}{c}0.12 \\
(0.07)\end{array}$ & $\begin{array}{c}0.37 \\
(0.09)\end{array}$ & $\begin{array}{c}0.30 \\
(0.08)\end{array}$ & $\begin{array}{c}0.25 \\
(0.08)\end{array}$ & 1.00 & 0.80 & 0.56 \\
\hline
\end{tabular}

*( )안의 값은 표준오차 값을 나타냄

\subsection{3 가설검정 결과}

본 논문의 연구모형과 가설을 검정하기 위하 여 구조방정식 모델 분석을 통하여 모형의 적 합도와 모수들을 추정하였다. 분석결과 제안모형 의 적합도는 $\chi^{2}=127.81(\mathrm{df}=65, \mathrm{p}=0.00)$, NNFI $=0.91$. RMSEA $=0.06, \quad \mathrm{CFI}=0.94, \mathrm{GFI}=0.94$, $\mathrm{AGFI}=0.90$ 으로 나타나 만족스러운 것으로 보 인다(〈그림 2〉 참조).

가설 1, 2는 '산업재 구매에서 물류환경의 불 확실성이 높을수록 물류서비스(가설 1)와 관계 규범(가설 2)에 정 $(+)$ 의 영향을 준다 이다. 경 로분석 결과 각각 경로계수가 $-0.03,0.02, \mathrm{t}$ 값 이 $-0.59,0.64$ 로 $a=0.05$ 의 수준에서 둘 다 기 각되었다(〈그립 2〉 참조). 기대와는 달리 물류 환경 불확실성이 물류서비스와 관계규범에 영 향을 주지 못한 이유는 거대기업인 발주처가
중소기업인 자재공급업체들에 대해 거래선의 선정권 등을 가지고 있어 함을 가진 구매담당 자는 환경불확실성을 크게 인식하지 못하기 때 문인 것으로 볼 수 있다. 또한 물류환경 불확실 성이 있다 하더라도 구매업무에 별다른 지장을 주지 않는 것으로 해석할 수 있다.

가설 3,4 는 '산업재 구매에서 높은 물류정보 화 수준은 물류서비스(가설 3)와 관계규범(가 설 4)에 정 $(+)$ 의 영향을 준다 이다. 경로분석 결과 가설 3 은 경로계수가 $-0.18, t$ 값은 -1.57 로 $a=0.05$ 의 수준에서 기각되었고, 가설 4 는 경로계수가 $0.33, \mathrm{t}$ 값은 4.25 로 채택되었다. 물 류정보화는 직접적으로 물류서비스에 영향을 미치지는 않으나 관계규범에는 유의한 영향을 주는 것으로 나타났다.

가설 5, 6은 '산업재 구매에서 우수한 물류자 원은 물류서비스(가설 5)와 관계규범(가설 6) 
〈그림 2〉 연구모형의 경로계수

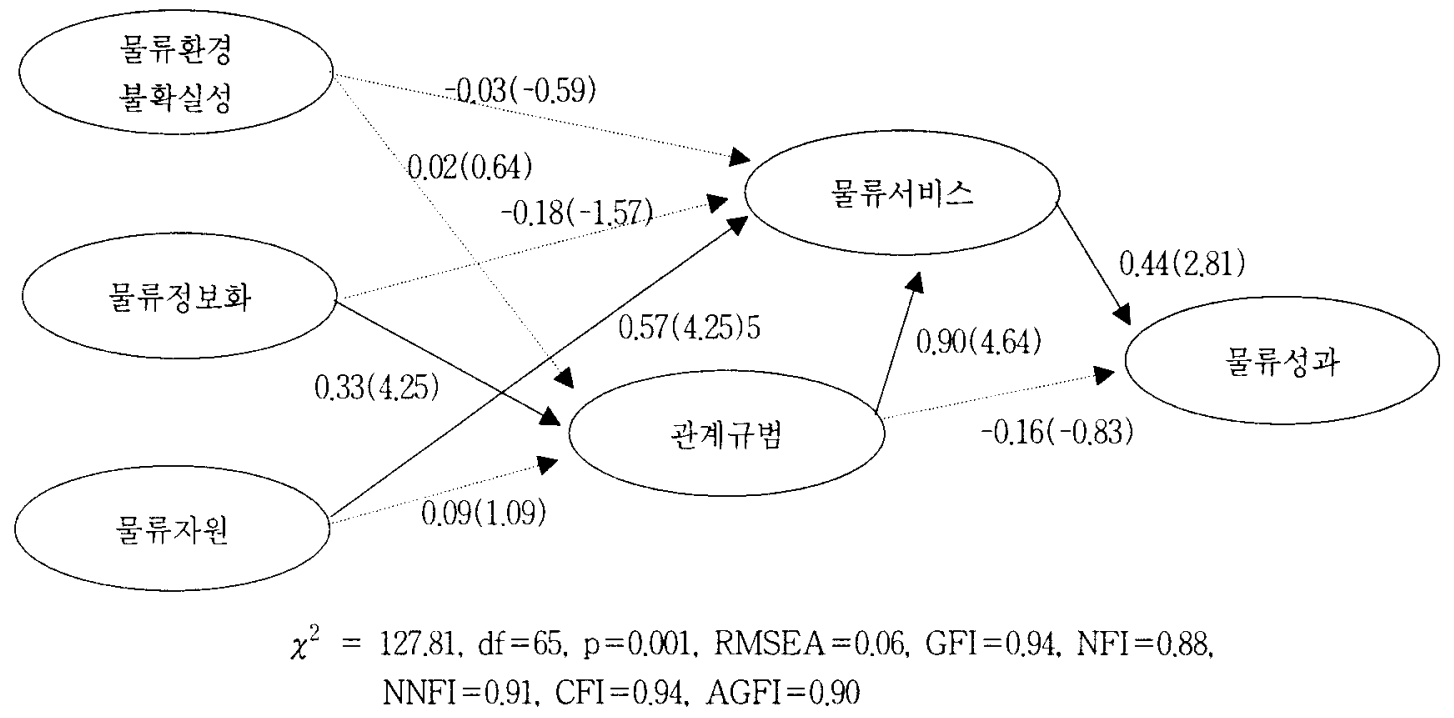

〈표 5〉 가설검정 결과

\begin{tabular}{|c|c|c|c|c|c|}
\hline & 가 설 & $\begin{array}{l}\text { 경로 } \\
\text { 명칭 }\end{array}$ & $\begin{array}{l}\text { 경로 } \\
\text { 계수 }\end{array}$ & $\mathrm{t}$ 값 & $\begin{array}{l}\text { 채택* } \\
\text { 여부 }\end{array}$ \\
\hline $\mathrm{H}_{\mathrm{l}}$ & 물류환경 불확실성 $\left(\xi_{1}\right) \rightarrow$ 물류서비스 $\left(\eta_{1}\right)$ & $\mathrm{v}_{11}$ & -0.03 & -0.59 & 기각 \\
\hline $\mathrm{H}_{2}$ & 물류환경 불확실성(炽) $\rightarrow$ 관계규범(n2) & $v_{21}$ & 0.02 & 0.64 & 기각 \\
\hline $\mathrm{H}_{3}$ & 물류정보화 $\left(\xi_{2}\right) \rightarrow$ 물류서비스 $\left(n_{1}\right)$ & $v_{12}$ & -0.18 & -1.57 & 기각 \\
\hline $\mathrm{H}_{4}$ & 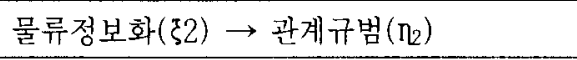 & $\mathbf{v}_{22}$ & 0.33 & 4.25 & 채택 \\
\hline $\mathrm{H}_{5}$ & 물류자원 $(\xi 3) \rightarrow$ 물류서비스 $\left(n_{1}\right)$ & $\mathrm{V}_{13}$ & 0.57 & 4.25 & 채택 \\
\hline $\mathrm{H}_{6}$ & 물류자원(§3) $\rightarrow$ 관계규범(n2) & $v_{23}$ & 0.09 & 1.09 & 기각 \\
\hline $\mathrm{H}_{7}$ & 관계규범 $\left(n_{2}\right) \rightarrow$ 물류서비스 $\left(n_{1}\right)$ & $\beta_{12}$ & 0.90 & 4.64 & 채택 \\
\hline $\mathrm{H}_{8}$ & 관계규범 $\left(\mathrm{n}_{2}\right) \rightarrow$ 물류성과 $\left(\mathrm{n}_{3}\right)$ & $\beta_{32}$ & -0.16 & -0.83 & 기각 \\
\hline $\mathrm{H}_{9}$ & 물류서비스 $\left(n_{1}\right) \rightarrow$ 물류성과 $\left(n_{3}\right)$ & $\beta_{31}$ & 0.44 & 2.81 & 채택 \\
\hline
\end{tabular}

${ }^{*} a=0.05$ 수준

에 정 $(+)$ 의 영향을 준다 이다. 경로분석 결과 가설 5 는 경로계수가 $0.57, \mathrm{t}$ 값은 4.25로 $\mathrm{a}=$ 0.05 의 수준에서 채택되었고, 가설 6 은 경로계 수가 0.09 , $\mathrm{t}$ 값은 1.09 로 기각되었다. 물류정보 화와 다르게 물류자원은 물류서비스에 직접적 인 영항을 주나 관계규범에는 유의한 영향을
주지 못하였다.

가설 7,8 은 '산업재 구매에서 거래기업간 관 계규범은 물류서비스(가설 7)와 물류성과(가설 8)에 정 $(+)$ 의 영향을 준다 이다. 경로분석 결 과 가설 7 은 경로계수가 $0.09, \mathrm{t}$ 값은 4.64로 $\mathrm{a}$ $=0.05$ 의 수준에서 채택되었고, 가설 8 은 경로 
계수가 $-0.16, \mathrm{t}$ 값은 -0.83 로 기각되었다. 구매 기업과 납품협력업체간의 높은 수준의 물류정 보화는 관계규범을 형성하고 이는 물류서비스 를 유의하게 높이는 것을 알 수 있으나, 관계규 범은 직접적으로 물류성과를 높이지 못하는 것 으로 나타났다. 마지막으로 가설 9는 '산업재 구매에서 높은 물류서비스 수준은 물류성과(가 설 9)에 정 $(+)$ 의 영향을 준다 이다. 경로분석 결과 가설 9 는 경로계수가 $0.44, \mathrm{t}$ 값은 2.81로 $a=0.05$ 의 수준에서 채택되었다. 많은 선행연구 결과와 일치하게 높은 수준의 물류서비스는 물 류성과를 유의하게 높이는 것으로 나타났다.

\section{V. 결 론}

\section{1 요약 및 논의}

본 논문은 중요성에 비해 선행연구가 거의 없 는 산업재 구매시장에서의 물류환경특성과 물 류정보화. 물류자원 등의 물류자원역량이 관계 규범과 물류서비스를 통하여 물류성과에 미치 는 영향을 분석하는 것을 주된 연구목적으로 한다. 제안한 연구가설들을 검정하기 위하여 $\mathrm{H}$ 중공업 및 $\mathrm{HSD}$ 엔진의 구매부, 자재관리부, 수 출입관리부, 외주관리부, 수입검사부 등의 물류 관련부서에 종사하는 핵심 응답자로부터 272 부 의 설문지를 수집하여 자료분석에 이용하였다.

구조방정식 모형 분석을 통해 알아낸 분석 결 과를 거시적으로 살펴보면, 산업재 구매환경에 서 물류환경 불확실성은 물류서비스와 관계규 범에 유의적인 영향을 주지 못하는 것으로 나
타났다. 물류자원역량은 구성요인의 특성에 따 라 차별적인 효과를 나타내었다. 예컨데 물류정 보화는 물류정보화 $\rightarrow$ 관계규범 $\rightarrow$ 물류서비스 $\rightarrow$ 물류성과의 경로로 유의한 영향을 주었으나 반면에 물류자원은 물류자원 $\rightarrow$ 물류서비스 $\rightarrow$ 물류성과의 경로로 유의한 영향을 주는 것으로 나타났다. 다시 말하면 물류정보화는 직접적으 로 물류서비스에 영향을 미치지 못하고 관계규 범을 통하여 간접적으로 물류서비스에 유의한 영향을 주었고, 반면에 물류자원은 관계규범에 는 영향을 주지 못하고 직접적으로 물류서비스 에 유의한 영향을 미치었다. 관계규범은 물류성 과에 영향을 주지 못하였으나 물류서비스는 물 류성과에 유의한 영향을 주었다.

연구주제별로 미시적 관점에서 분석한 결과를 토대로 실무적 시사점을 논의해보면 다음과 같 다. 첫째, 산업재구매에서 물류환경 불확실성은 물류서비스와 관계규범에 유의한 영향을 미치 지 않는 것으로 나타났다. 환경의 다양성. 가변 성이 높아 불확실성이 커질 때 산업재구매자와 납품업체간에 긴밀한 정보교환과 구매상황처리 의 유연성이 요구되고 또한 납품업체의 물류서 비스가 높아짐으로써 거래위험을 최소화하고 안정적인 협력관계를 형성할 것으로 기대하였 으나 분석결과는 다르게 나타났다. Droge and Germain(2000)의 연구에서도 물류수요환경의 가변성은 물류서비스와 재무성과에 유의한 영 향을 주지 않는 것으로 나타났는데, 이는 일반 적으로 산업재 구매자와 공급업체간의 관계가 힘의 불균형상태에 놓여 있기 때문에 시장에서 힘을 가진 우월한 위치에 있는 구매자입장에서 는 환경 불확실성에 별 상관없이 안정되게 소 싱을 하기 때문인 것으로 볼 수 있다. 
또한 Joshi and Campbell(2003)은 역동적 환 경하에서 구매자가 공급업체에 대한 관계적 지 배(relational governance)를 약화시키는 요인들 로 구매자의 협력적 신넘이 낮을 때와 공급업 체의 전문지식이 낮을 때를 제시하였다. 본 연 구의 표본인 구매자는 대기업으로 물류전문지 식이 높고 상대적으로 공급업체는 물류지식이 낮다고 볼 수 있기 때문에 구매자는 환경의 역 동성에 대처하기 위하여 공급업체와의 정보교 환 등의 관계규범을 크게 형성할 필요성을 느 끼지 못하기 때문인 것으로 유추해 볼 수 있다.

둘째, 물류자원역량의 구성요인 중의 하나인 물류정보화는 관계규범을 통하여 물류서비스에 영향을 주는 것으로 나타났다. 산업재는 사양변 경, 납기조정, 포장방법 등 구매조건이 복잡하 기 때문에 물류정보시스템을 통하여 실시간으 로 정보를 교환함으로써 운영비용을 절감할 수 있는 이점이 있다. 이때 거래의 신뢰성을 확보 하고 LIS가 제대로 작동되기 위해서는 투명한 정보교환, 운영상의 탄력성 등의 관계규범이 반 드시 수반되어야 한다. 따라서 먼저 산업재구매 자와 납품업체간에 LIS가 잘 구축이 되고 효율 적으로 작동되어야 거래당사자간의 합의된 관 계규범도 더욱 공고해지고 이는 제품가용성, 배 송적시성 등의 질 높은 물류서비스를 거래파트 너에게 제공할 수 있는 것을 알 수 있다.

셋째, 물류자원능력은 물류서비스에 직접적인 영향을 미치는 것으로 나타났다. 이러한 결과는 산업재 구매에서 물류서비스의 핵심이 구매자 재에 대한 적시성과 제품가용성에 두는 만큼 자재공급업체의 수송차량, 하역장비의 보유, 유 능한 수송인력, 배송루트 등의 물류 프로세스 및 물류지식에 대한 중요성을 보여주는 것이다.
이는 산업재구매자가 필요한 자재를 적절한 시 간에 배송받을 수 없다면 제조과정에서 생산지 연상황이 발생해 궁극적으로 최종소비자의 불 만족을 초래하고 판매상실로 이어져 값비싼 결 과를 가져올 수 있기 때문이다. 그러나 우수한 물류자원을 보유하고 있다는 자체만으로는 관 계규범이 형성되지 않음을 볼 수 있다.

넷째, 관계규범은 선행연구 결과(Dahlstrom et al. 1996)와 일치하게 물류서비스에 유의한 영 향을 주는 것으로 확인되었다. 산업재거래는 일 반적으로 장기적 거래를 보이는데 초기에는 복 잡한 계약을 바탕으로 형식화된 거래형태를 띠 우나 시간이 경과함에 따라 거래관계를 조정하 는 관계규범이 중요한 거래 메커니즘으로 작용 한다. 따라서 산업재구매자와 자재공급업체간의 원활한 정보교환과 운영유연성은 이해관계와 상호간의 거래부담을 조정함으로써 기대에 어 긋나는 일탈적인 행동을 방지하고 제품가용성 과 적시배송의 물류서비스를 제공하는 것으로 유추할 수 있다.

다섯째, 관계규범은 물류성과에 중요한 영향 을 미치지 못하였으나 물류서비스는 물류성과 에 유의한 영향을 주었다. 먼저 거래당사자간에 합의된 관계규범은 물류성과에 영항을 줌으로써 기업성과를 향상시킨다는 선행연구(Dahlstrom et al. 1996)와는 다르게 관계규범은 물류성과 를 의미있게 높이지 못하였다. 다수의 조직이 관여하는 산업재 구매환경은 이질적이고 가변 적이어서 제반 불확실성과 위험을 줄이기 위하 여 거래당사자간의 관계규범이 형성되면 당연 히 관계규범이 물류성과에 긍정적인 영향을 미 칠 것으로 기대하였다. 그러나 앞의 논의대로 거래당사자간의 합의된 관계규범은 물류서비스 
를 유의하게 높이는 것으로 나타났으나 물류비 용절감, 배송의 질 등의 물류성과의 제고에는 별다른 효과를 나타내지 못하였다.

반면에 물류서비스는 물류성과에 유의한 영향 을 주는 것으로 나타났다. 물류성 과는 직접적으 로 실제 수행된 하드웨어적인 물류서비스에 의 해서 향상되고, 소프웨어적인 관계규범은 물류 서비스를 통하여 간접적으로 물류성과에 영향 을 주는 것을 알 수 있다. 많은 선행연구들의 결과와 일치하게 장기적 관계를 기반으로 하는 산업재구매자와 자재공급업자의 거래에서 관계 규범을 바탕으로 한 우수한 물류서비스는 리드 타임 일관성, 배송품질 향상 등의 물류성과에 유의한 영향을 주었다. 이러한 결과는 산업재구 매에서 납품업체의 품절 없는 재고가용성, 정시 배송 등의 물류서비스가 물류성과를 높이는 필 수요인임을 알 수 있게 한다.

\section{2 연구의 한계점 및 미래 연구방향}

본 논문은 학문적, 실무적 중요성에 비해 연 구가 별로 되어있지 않은 산업재 납품업체와 조직구매자 간의 산업재 물류에 대한 연구로서 가장 큰 공헌점은 성공적인 물류관리를 위한 핵심요인들을 규명하고 이들 구성요인들이 물 류성과에 미치는 영향을 실증적으로 보여주었 다는데 있다. 본 논문에서 밝혀진 물류환경, 물 류정보화, 물류자원, 관계규범, 물류서비스 및 물류성과 간의 연관관계에 대한 분석결과들은 산업재 구매자들에게 이론에 근거한 전략적 물 류관리 실천방안으로 활용될 수 있을 것이다.

이러한 공헌점과 아울러 본 논문은 다음과 같 은 한계점들을 가지고 있다. 첫째, 본 논문은
산업재구매자의 관점에서 연구한 논문인데 산 업재구매자는 산업과 업종의 특성상 많은 응답 자를 획득하기가 쉽지 않은 문제가 있다. 따라 서 본 연구에서는 제한된 업종에 종사하는 물 류관련 핵심응답자 167 명으로부터 각 응답자가 2개의 납품업체를 평가하도록 하여 자료를 수 집하였다. 물론 이 과정에서 중복평가를 방지하 기 위한 노력이 있었으나 설문응답의 중복성과 신뢰성의 문제가 제기될 수 있다. 차후의 연구 에서는 다수의 동종기업뿐만 아니라 다른 산업 의 물류기업을 포함하여 좀 더 풍부한 자료 수 집을 해야 할 것이다.

둘째, 분석결과의 일반화와 정확한 시사점을 도출하기 위하여 납품공급업체를 대상으로 제 안한 연구모형과 가설들을 검증해 볼 필요가 있다. 특히 가능하다면 산업재구매자와 납품공 급업체를 이원적(dyadic)으로 연결하여 실증분 석해 볼 필요가 있다. 셋째, 연구모형에서 사용 되고 있는 7 개 중 3 개 구성개념에서 측정항목 들이 척도 정제과정에서 제거되어 2 개의 측정 항목들만 이용되었다. 〈표 3〉에서 보듯이 측정 항목들은 대응하는 구성개념을 잘 나타내어 내 용타당성은 확보되는 것으로 볼 수 있다. 그러 나 원론적으로 적어도 3 개 이상의 측정항목을 이용하여 구성개념을 측정하여야 좀 더 정확하 게 대응 구성개념을 반영할 수 있다는 점에서 보면 미흡한 점이 있다.

넷째, 이 연구에서는 다차원적인 물류환경 불 확실성 개념을 제한된 측정항목으로 단일차원 으로 간주하고 측정하였다. 앞으로의 연구에서 는 산업재 물류의 불확실성을 대변할 수 있는 역동성, 이질성. 적대성 등의 다차원적이고 정 교화된 개념들과 측정항목들을 사용하여 심도 
있는 분석을 할 필요가 있다.

다섯째, 본 논문에서는 물류역량으로 물류정 보화와 물류자원만을 구성요인으로 보았다. 특 히 물류자원의 구성개넘신뢰도(0.52)와 분산추 출값(0.36)이 기준치보다 작게 나와 집중타당성 에 문제가 있다고 판단되었으나 이 개념의 본 논문에서의 이해타당도가 중요하다고 생각되어 통계적 취약성에도 불구하고 사용하였다. 미래연 구에서는 Olavarrieta and Ellinger(1997). Zhao et al.(2001) 등이 제시한 고객중심역량, 자원중 심역량. 정보중심역량을 모두 포괄적으로 사용하 여 물류역량을 심층적으로 분석할 필요가 있다. 여섯째, 본 연구에서는 행위적 매개변수로서 관계규범을 사용하였다. 향후 연구에서는 성공 적인 구매자-판매자 관계에서 필수불가결한 개 념인 신뢰를 이용하여 산업재 물류당사자들간 의 관계의 질을 측정할 필요가 있다. 일곱째, 물류서비스와 물류성과에 관한 연구들의 근본 적 한계점인 물류서비스와 물류성과를 측정하 는 항목들의 명목타당성(face validity)의 문제 가 본 논문에서도 여전히 존재한다.

마지막으로 향후 연구에서 위에서 언급한 한 계점들을 보완하면서 산업재물류에 대한 심층 연구를 한다면 현장에 근거한 시사점들을 도출 하여 물류관련 기업들의 기업이념, 목표 및 전 략수립에 가치있게 반영할 수 있을 것이다.

〈논문 접수일: 2005. 10. 12〉

〈게재 확정일: 2006. 03. 13〉

\section{참 고 문 헌}

김태현, 문성암(1998), “공급체인 구성원간 물류 서비스 인식의 관련성에 관한 연구," 로지 스틱스 연구, 6(1), 57-72.

김용철, 김재일(2001), "물류 성과 측정에 있어 서 성과 차원 및 측정 척도에 관한 연구." 로지스턱스 연구, 9(1), 65-87.

김재욱, 박광태, 이성근, 최지호(2000), "SCM이 물류 서비스와 물류 성과에 미치는 영향."

로지스턱스 연구, 8(1), 51-63.

노승혁, 김철민, 서근하(2003), "물류정보시스템

의 활용도가 물류성과에 미치는 영향에 관

한 연구," 중소기업연구, 25(3), 299-327.

대한상공회의소(2004), 기업물류비 현황조사 보 고서.

전달영, 정창환(1997), "물류서비스 역량과 상표 력이 시장점유율에 미치는 영향: 세제·생 활용품 산업을 중심으로," 로지스틱스 연 구, 5(2), 139-154.

Achrol, Ravi S. and Louis W. Stern(1988), "Environmental Determinants of DecisionMaking Uncertainty in Marketing Channels," Journal of Marketing Research, 25(Feb.). $36-50$.

Achrol, Ravi S., Toger Reve, and Louis W. Stern(1983), "The Environment of Marketing Channel Dyads: A Framework for Comparative Analysis," Journal of Marketing, 47(Fall), 55-67.

Anderson, J.C. and D.W. Gerbing(1988), "Structural Equation Modeling in Practice: A 
Review and Recommended Two-Step Approach," Psychological Bulletin, (May), 411-423.

Ballou, Ronald H.(2001), Business Logistics Management. 5rd Ed.. NJ: Prentice Hall. Barney. Jay B.(1991), "Firm Resources and Sustained Competitive Advantage," Journal of Management, 17(1), 99-120.

Bourlakis, Constantine and Michael Bourlakis (2005), "Information Technology Safeguards, Logistics Asset Specificity and Fourthparty Logistics Network Creation in the Food Retail Chain." Journal of Business \& Industrial Marketing, 20(2). 88-98.

Bowersox, Donald J., Patricia J. Daugherty, Cornelia L. Droge, Dale S. Rogers, and Daniel L. Wardlow(1989), Leading Edge Logistics: Competitive Positioning for the 1990s. Oak Brook. IL: Council of Logistics Management.

Bowersox, Donald J.. Patricia J. Daugherty, Cornelia L. Droge, Richard Germain, and Dale S. Rogers(1992). Logistical Excellence: It 's not Business as Usual. Bedford. MA: Digital Press.

Bowersox, D. J., D. J. Closs, and T. P. Stank (1999), 21st Century Logistics: Making Supply Chain Integration a Reality, Council of Logistics Management, Oak Brook, IL. Child, J.(1972), "Organization Structure. Environment, and Performance: The Role of Strategic Choice," Sociology, 6, 1-22.

Closs, David J., Morgan Swink, and Anand
Nair(2005), "The Role of Information Connectivity in Making Flexible Logistics Programs Successful," International Journal of Physical Distribution \& Logistics Management, 35(4), 258-277.

Dahlstrom, Robert, Kevin M. McNeilly, and Thomas W. Speh(1996), "Buyer-Seller Relationships in the Procurement of Logistical Services," Journal of the Academy of Marketing Science, 24(2), 110-124.

Daugherty, Patrica J., Theodore P. Stank, and Alaxander E. Ellinger(1998), "Leveriging Logistics/Distribution Capabilities: The Effect of Logistics Service on Market Share," Journal of Business Logistics, 19(2), 35-51. Droge, Cornelia and Richard Germain(2000). "The Relationship of Electronic Data Interchange with Inventory and Financial Performance," Journal of Business Logistics. 21(2), 209-230.

Ganesan, Shankar(1994), "Determinants of Longterm Orientation in Buyer-Seller Relationships," Journal of Marketing, 58(April), 1-19.

Hair, J.W., R.E. Anderson, R.L. Tatham, and W.C. Black(1998), Multivariate Data Analysis, 5th ed, Englewood Cliffs: Prentice Hall. Heide, Jan B. and George John(1992), "Do Norms Matter in Marketing Relationship?" Journal of Marketing, 56(April), 32-44. Jayaram, J., S. K. Vickery, and C. Droge(2000), "The Effects of Information System Infrastructure and Process Improvements on 
Supply-chain Time Performance," International Journal of Physical Distribution \& Logistics Management, 30(3/4), 314-330.

Joshi, Ashwin W. and Alexandra J. Campbell (2003), "Effect of Environmental Dynamism on Relational Governance in ManufacturerSupplier Relationships: A Contingency Framework and an Empirical Test," Journal of the Academy of Marketing Science, 31(2), 176-188.

Kaufmann, Pattrick J. and Louise W. Stern (1988), "Relational Exchange Norms, Perceptions of Unfaimess, and Retained Hostility in Commercial Litigation," Journal of Conflict Resolution, 32(Sep.), 534-552.

Khandwalla, P.(1972). The Design of Organizations. New York: Harcourt.

Kent, John L. and John T. Mentzer(2003), “The Effect of Investment in Interorganizational Information Technology in a Retail Supply Chain," Journal of Business Logistics, 24(2), 155-175.

LaLonde, Bernard J.(1985), "Customer Service" in J. F. Robeson and R. G. House eds., The Distribution Handbook, New York, The Free Press.

LaLonde, Bernard $\mathrm{J}$, and Paul H. Zinszer (1976). Customer Service: Meaning and Measurement. Chicago, IL: National Council of Physical Distribution Management.

Lawrence, P. and J. Lorsch(1967), Organization and Environment. Cambridge, MA: Harvard University Press.
Lieb. Richard and J. Miller(2002). The Use of Third-party Logistics Services by Large US Manufacturers.

Lusch, Robert F. and James R. Brown(1996), "Interdependency, Contracting, and Relational Behavior in Marketing Channels," Journal of Marketing, 60(Oct.), 19-38.

Macneil, Ian R.(1980), The New Social Contract: An Inquiry into Modern Contractual Relations, New Haven, CT: Yale University Press.

March, J. G. and H. A. Simon(1958), Organizations, John Wiley \& Sons, New York.

McGinnis, M. A. and J. W. Kohn(1993), "Logistics Strategy, Organizational Environment, and Time Competitiveness," Journal of Business Logistics, 14(2), 1-23.

Mentzer, John T., Roger Gomes, and Robert Kraphel, Jr.(1989), "Physical Distribution Service: A Fundamental Marketing Concept," Journal of the Academy of Marketing Science, 17(1), 42-53.

Mentzer, John T., Daniel J. Flint, and John L. Kent(1999), "Developing Logistics Service Quality Scale," Joumal of Business Logistics, 20(1), 9-32.

Mentzer, John T., Daniel J. Flint, and G. Tomas M. Hult(2001), "Logistics Service Quality as a Segment-Customized Process," Journal of Marketing, 65(October), 82-104.

Miller. Danny and Peter H. Friesen(1982), "Innovation in Conservative and Entrepreneurial Firms: Two Models of Strategic 
Momentum," Strategic Management Journal, 3, 1-25.

Miller, Danny and Peter H. Friesen(1983), "Strategy-making and Environment: The Third Link." Strategic Management Journal, 4. 221-235.

Nunnally, J.C.(1978), Psychometric Theory, New York: McGraw-Hill.

Olavarrieta, Sergio and Alexander E. Ellinger (1997), "Resource-based Theory and Stratgic Logistics Research." Journal of Physical Distribution \& Logistics Management. 27 (9/10), 559-587.

Perrault. William D. and Frederick Russ(1974), "Physical Distribution Service: A Neglected Aspect of Marketing Management," MSU Business Topics, 22(Summer), 37-45.

Prahalad, C. K. and Gary Hamel(1990). "The

Core Competence of the Corporation," Harvard Business Review, 68(May -June), 71-91.

Shapiro, Roy D.(1984). "Get Leverage from Logistics," Harvard Business Review, 62 (May-June), 119-126.

Sharma, Arun, Dhruv Grewal, and Michael Levy (1995),"The Customer Satisfaction / Logistics Interface," Journal of Business Logistics, 16(2), 1-21.
Stank, Theodore P., Thomas J. Goldsby, and Shawnee K. Vickery, and Katrina Savitskie (2003), "Logistics Service Performance: Estimating Its Influence on Market Share," Journal of Business Logistics, 24(1), 27-55. Sterling, Jay U. and Douglas M. Lambert (1989), "Customer Service Research: Past, Present and Future," Journal of Physical Distribution \& Materials Management, 19(2), 3-23.

Stock, James R. and Douglas M. Lambert (2004), Strategic Logistics Management. 4th ed.. Homewood, IL: Irwin.

Thompson, J. D.(1967), Organizations in Action, McGraw-Hill, New York.

Wernerfelt. Birger(1984), "A Resource-based View of the Firm," Strategic Management Journal, 5(2), 171-180.

Wisner, Joel D.(2003), “A Structural Equation Model of Supply Chain Management Strategies and Firm Performance." Journal of Business Logistics, 24(1), 1-26.

Zhao, Meng. Cornelia Droge, and Theodore P. Stank(2001), "The Effects of Logistics Capabilities on Firm Performance: Customerfocused versus Information-focused Capabilities." Journal of Business Logistics, 22(2), 91-107. 


\title{
The Impact of Environmental Uncertainty and Logistics Resources Capabilities on Logistics Performance through Relational Norms and Logistics Services in the Industrial Products
}

\author{
Dal-Young Chun* \\ Hong-Sun Kim**
}

\begin{abstract}
The major purpose of this study is to investigate the impact of environmental uncertainties and logistics resources capabilities mediated by relational norms and logistics services on logistics performance in the industrial products. The 272 data were collected from the key informants who were working at the logistics-related departments in the H Heavy Industries \& Construction and HSD Engine. The following results were verified using structural equation modeling. First, environmental uncertainties such as dynamism and heterogeneity unexpectedly had insignificant effects on relational norms such as information exchange and flexibility and logistics services such as product availability and on-time delivery. Second, logistics resource capabilities showed unique effects based upon its component's characteristics. For example, Logistics Information Systems did not have direct impact on logistics services but had indirect effect on logistics services via relational norms. On the other hand, logistics resources such as logistics specific assets and transportation service competencies had direct impact on logistics services but not on relational norms. Third, relational norms between transaction partners significantly affected logistics services but had insignificant effects on logistics performance such as logistics costs reduction and delivery qualities. Fourth, consistent with several studies, excellent logistics services between industrial purchaser and suppliers based upon relational norms did have significant effect on logistics performance such as delivery consistency and delivery qualities. Finally, the empirical results in this study could be strategic logistics management guidelines based upon the theoretical relationships among the environmental uncertainties, logistics information systems, logistics resources, relational norms, logistics services, and logistics performance.
\end{abstract}

Keywords: industrial logistics, environmental uncertainties, logistics resources capabilities, relational norms, logistics services, logistics performance

\footnotetext{
* Professor, School of Business, Chungbuk National University

** President, SUN ALL E\&C
} 